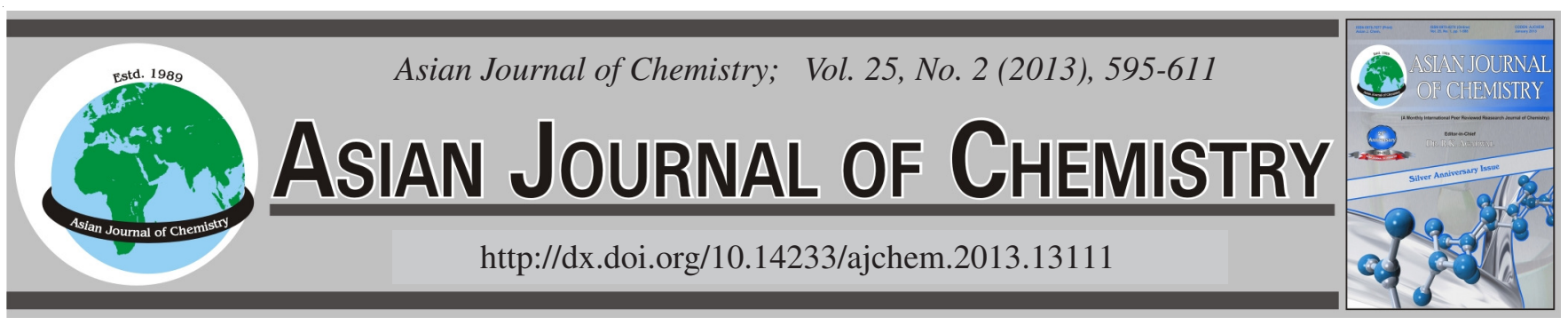

\title{
REVIEW
}

\section{Kinetics and Mechanism of Oxidation of Reducing Sugars: A Review}

\section{J.V. Singh ${ }^{1, *}$, Anupam Awasthi $^{1}$, Dipti $^{2}$, Ashish Tomar $^{2}$ and Devendra Singh ${ }^{3}$}

${ }^{1}$ Department of Chemistry, Nehru College, Chhibramau-209 721, India

${ }^{2}$ Department of Chemistry, Meerut College, Meerut-250 001, India

${ }^{3}$ Faculty of Engineering and Technology, Chandra Shekhar Azad University of Agriculture and Technology Campus, Etawah-206 001, India

*Corresponding author: E-mail: jvsingh1@ @otmail.com

This review summaries the kinetic and mechanistic aspects of the oxidation reaction of reducing sugars with various oxidants, with emphasis to the $\mathrm{Cr}(\mathrm{VI})$ oxidation of reducing sugars. An attempt has been made to cover the recent literature available on oxidation kinetics of reducing sugars upto June 2011.

Key Words: Oxidation, Kinetics, Mechanism, Reducing sugars.

\section{INTRODUCTION}

Carbohydrates including sugars are multifunctional naturally occurring material, the oxidation products of which play a key role as intermediates for the synthesis of more complex molecules and also display, in many cases, varied biological activities. Although a number of oxidation procedure for carbohydrates have been developed but clear information or an overall view on the kinetics and mechanism of reducing sugars with various oxidants is lacking which promoted us to document an overall view on the oxidation of reducing sugars. Earlier Capon's review ${ }^{1}$ recorded the complex reaction mechanism in carbohydrate chemistry. Varela ${ }^{2}$ in his review updated the treatment of the subject in a review by Green ${ }^{3}$. Kinetic studies on the oxidation of reducing sugars by various metal ions in acidic and alkaline medium have been reported in an another review by Bhatnagar et al. ${ }^{4}$ and a review by Rangappa ${ }^{5}$ included the kinetic and mechanistic studies on the oxidation of monosaccharides (such as erythrose and therose series, pentoses and hexoses, 6-deoxyhexoses, aminosugars and uronic acid) with all available $\mathrm{N}$-metallo-N-halo aryl sulfonamides in alkaline medium. A review of the subject by Odebunmi and Ogunlaja ${ }^{6}$ focusing on homogeneous catalytic oxidation of some sugars using different metal and metal complex as catalyst has appeared recently. Kinetic and mechanistic studies on oxidation of reducing sugars reported other than in these reviews except some studies in Varela's review ${ }^{2}$ are included herein this review article.
Reducing sugar in solution: A reducing sugar, may exist in solution as acyclic aldehydes, the corresponding hydrates, $\alpha$ - and $\beta$-pyranoses and as $\alpha$ - and $\beta$-furanoses (Scheme-I) ${ }^{7}$.

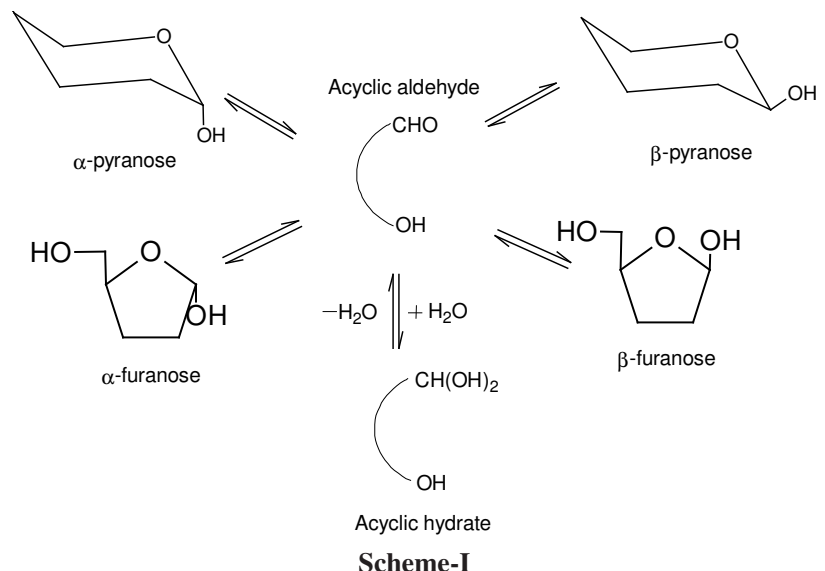

The kinetics and mechanism of the oxidation reaction depends on the nature of reducing sugar in solution, the active species of the oxidant used and the $\mathrm{pH}$ of the medium. The kinetic study of carbohydrates have been carried out both in alkaline as well as in acidic medium.

Oxidation of reducing sugars in alkaline medium: The reducing sugar molecule isomerises in alkaline solution to an intermediate enediol. 
<smiles>C=CCC(O)C(O)C=O</smiles><smiles>CCOCCCCCO</smiles><smiles>C=CC(=O)C(C)O</smiles>

In most of the oxidation of reducing sugars in alkaline medium, a mechanism involving enolization step and the intermediate enediol has been proposed.

The kinetics of oxidation of D-xylose, L-arabinose, D-mannose and D-galactose ${ }^{8}$ and sorbose $^{9}$ by chloramine-T (CAT) led to the rate law:

$$
-\frac{\mathrm{d}[\mathrm{CAT}]}{\mathrm{dt}}=\mathrm{k}[\mathrm{CAT}][\text { substrate }]\left[\mathrm{OH}^{-}\right]^{2}
$$

A rate-determining reaction of hypochlorite ion and the anion of the aldose has been proposed (Scheme-II).

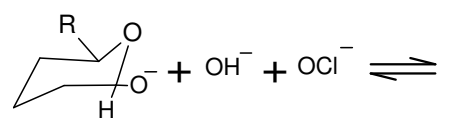

$\beta$-pyranose anion

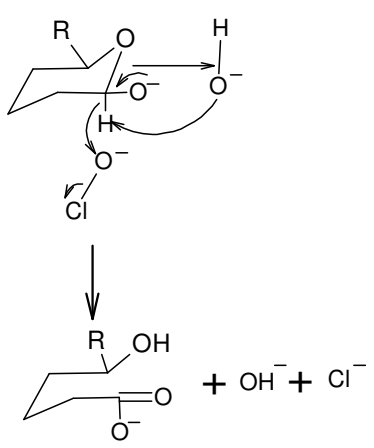

aldonic acid anion
Scheme-II

The oxidation of fructose and dulcitol ${ }^{10,11}$ by chloramine-T shows a first order dependence in [alkali]. From the zero order dependence in [bromamine-T] (BAT) and first order in [sugar] and [alkali] at lower concentrations and zero order in [alkali] at higher concentrations in the oxidations of some hexoses like D-glucose, D-fructose, D-galactose and D-mannose by bromamine-T in alkaline solution, Singh and Prakash ${ }^{12}$ proposed that the rate determining step is the formation of enediol anion which reacts rapidly with the oxidant.

Based on the first order dependence of rate on [oxidant] and [substrate] and second order on $\left[\mathrm{OH}^{-}\right]$in the oxidation of D-galactose, L-sorbose and D-xylose ${ }^{13}$ by bromamine-T and bromamine-B in alkaline medium, the following reaction sequence (Scheme-III) has been proposed.

The kinetics of oxidation of L-fructose, D-fructose and L-rhamnose ${ }^{14}$ by bromamine-B is first order in [oxidant] [sugar] and $\left[\mathrm{OH}^{-}\right]$in alkaline medium. A mechanism involving an enediol anion $\left(\mathrm{E}^{-}\right)$of sugar reacts with the oxidant in the rate determining step has been proposed.

N-Bromo-arylsulfonamides of different oxidizing strengths have been used for studying the oxidation kinetics of D-fructose and D-glucose in aqueous alkaline medium and the results have been analyzed and compared with those from the sodium salts of N-bromo-benzenesulfonamides and $\mathrm{N}$ bromo-4-methyl-benzenesulfonamide ${ }^{15}$. The reactions show

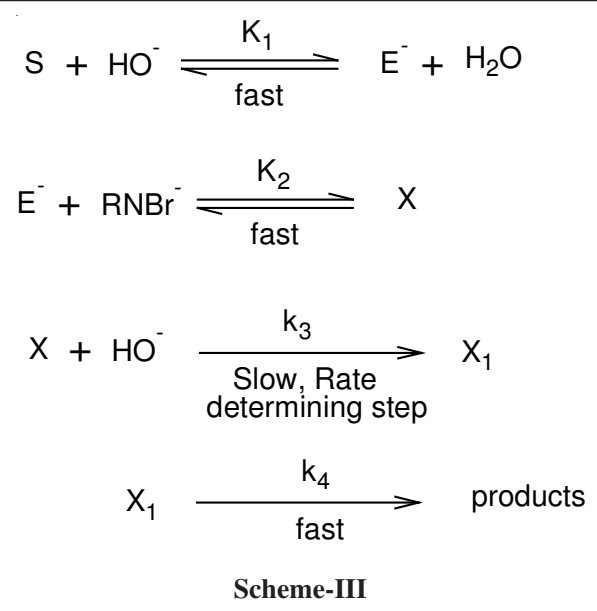

zero order kinetics in [oxidant], fractional order in [fructose/ glucose] and nearly first order in $\left[\mathrm{OH}^{-}\right]$.

Nine sodium salts of mono and di-substituated N-chloroarylsulfonamides have been employed as an oxidant for studying the kinetics of oxidation of D-fructose and D-glucose in alkaline medium ${ }^{16}$. The reactions show first order kinetics each in [oxidant], [substrtate] and $\left[\mathrm{OH}^{-}\right]$.

Kinetic studies on the oxidation of galactose and mannose ${ }^{17}$, arabinose and xylose ${ }^{18}$, maltose and lactose ${ }^{19}$ and melibiose and cellobiose $\mathrm{e}^{20}$ by iodine in alkaline solution have indicated that the active oxidizing species is hypoiodus acid.

The study of non-catalyzed molecular reaction of reducing sugars $^{21}$ (galactose and fructose) with iodine in an alkaline medium indicate that the reaction follows first order kinetics with respect to sugars, hypoiodous acid and zero order kinetics with respect to iodine concentration. The proposed reaction mechanism involves the formation of intermediate complex (Scheme-IV).

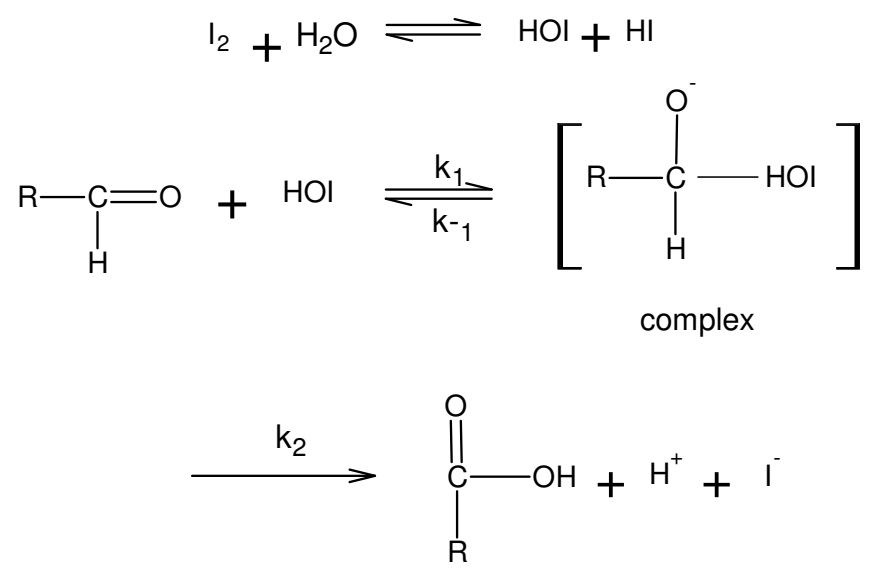
Scheme-IV

The kinetics of oxidation of maltose and lactose by $\mathrm{Cu}$ (II) in presence of $\mathrm{NH}_{4} \mathrm{OH}$ revealed that the reaction proceed after a slight induction period and the rate of reaction is zero order in [oxidant] and first order in [sugar] and $\left[\mathrm{OH}^{-}\right]$. The rate determining step involves the reaction between hydroxyl ion and reducing sugar, leading to an intermediate active product which is rapidly oxidized by $\mathrm{Cu}$ (II) complex through an electron transfer process $^{22}$. 
Kinetic studies have also been reported for the reaction of $\mathrm{Cu}$ in presence of ammonia with maltose, lactose, melibiose and cellobiose $\mathrm{e}^{23}$.

The results of comparative studies on kinetics of catalyzed oxidation of glucose and galactose by hexacynoferrate(III) ion and $\mathrm{CuSO}_{4}$ in alkaline medium show that the rate of oxidation increased with increase in substrate concentration, temperature, ionic strength as well as $\mathrm{pH}^{24}$. The positive effect of catalyst was observed with $\mathrm{Cu}^{2+}$ in the reaction of galactose but not in glucose with hexacynoferrate(III) as oxidant. Oxidation of both sugars with $\mathrm{CuSO}_{4}$ as oxidant was found not to enhance by $\mathrm{Cr}^{3+}$.

The rate of the oxidation reaction of $\mathrm{D}$-xylose, D-ribose and L-arabinose by 1-chlorobenzotriazole (CBT) in $\mathrm{NaOH}$ is first order in [CBT] and fractional order each in [sugar] and $\left[\mathrm{OH}^{-}\right]^{25}$. From reaction product, salt effect, dielectric constant effect, solvent isotope effect, a mechanism having $\mathrm{C}_{1}-\mathrm{O}-\mathrm{Cl}$ intermediate has been proposed (Scheme-V).

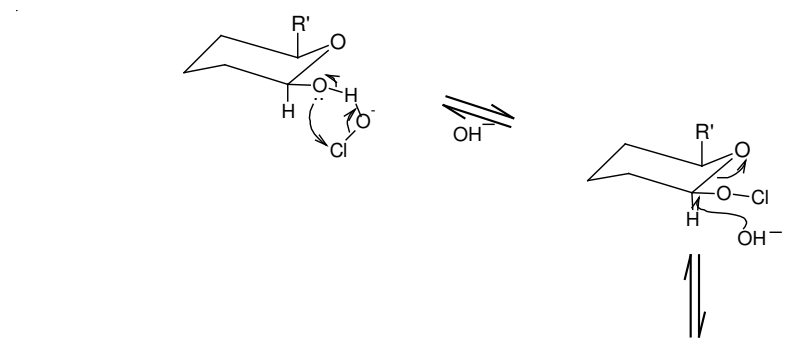

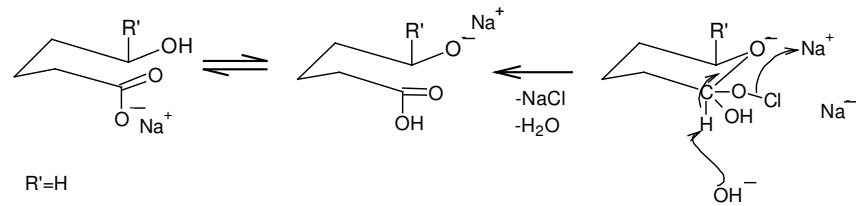

Scheme-V

Oxidation kinetics of D-glucose, D-galactose, D-mannose and D-fructose by $t$-butyl hypochlorite $(t-\mathrm{BuOCl})$ in alkaline

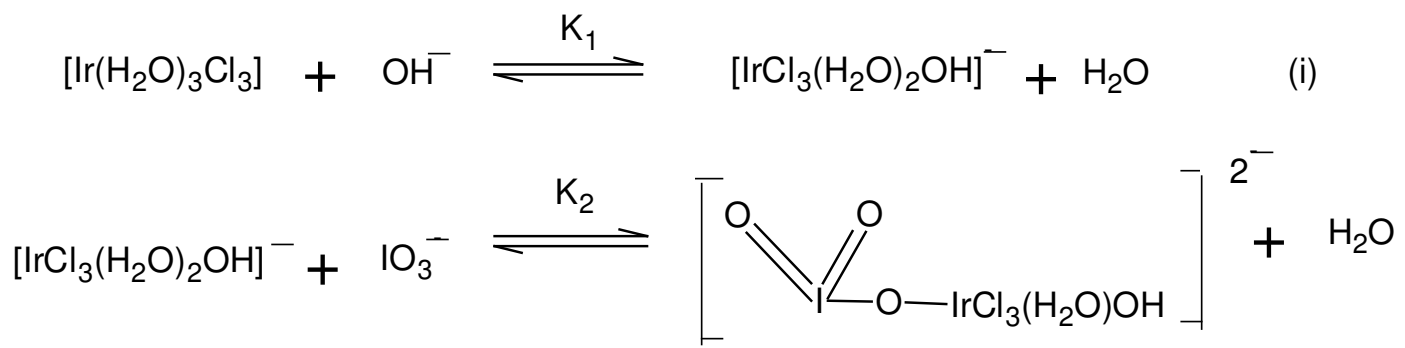<smiles></smiles>

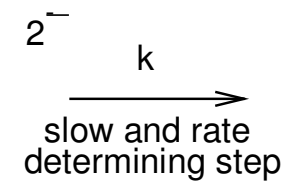

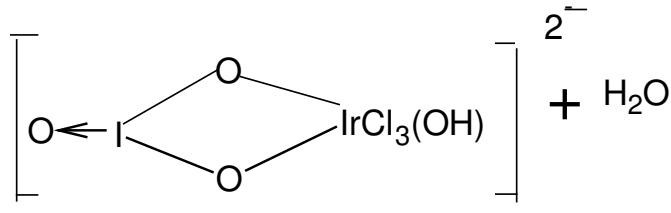<smiles>OC(O)=C(O)C1CCCC1</smiles><smiles>[R]C([O-])(O)C=[C-]COOCCO</smiles>

$+10_{2}^{-}$

Where $R$ stands for $\mathrm{C}_{3} \mathrm{H}_{7} \mathrm{O}_{3}$

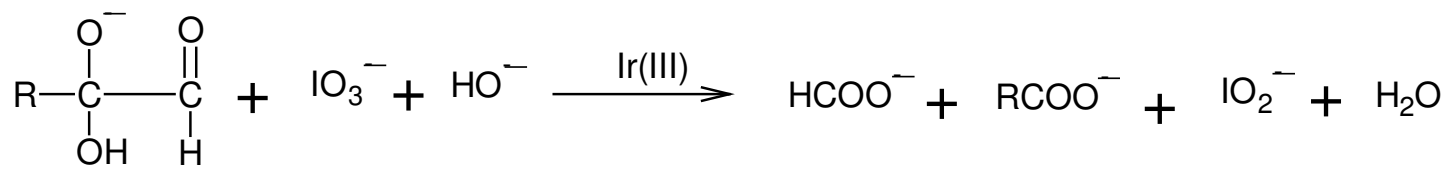

$$
\left[\mathrm{IrCl}_{3}\left(\mathrm{H}_{2} \mathrm{O}\right)(\mathrm{OH})_{2}\right]^{-2}+2 \mathrm{H}_{2} \mathrm{O} \longrightarrow\left[\mathrm{IrCl}_{3}\left(\mathrm{H}_{2} \mathrm{O}\right)_{3}\right]+2 \mathrm{HO}^{-}
$$

\section{Scheme-VI}


medium follows both zero and first order pathways in $[t-\mathrm{BuOCl}]$ and fractional order kinetics each in [hexose] and $\left[\mathrm{OH}^{-}\right]^{26}$. The order of reactivity is D-fructose $>$ D-glucose $\approx$ D-galactose $>$ D-mannose.

$\mathrm{Ru}$ (VIII) catalyzed oxidation of L-sorbose and maltose by sodium metaperiodate in alkaline medium shows first order kinetics with respect to $\left[\mathrm{NaIO}_{4}\right],[\mathrm{Ru}(\mathrm{VIII})]$ and $\left[\mathrm{OH}^{-}\right]$at their low concentration and zero order at high concentration. The reaction follows identical kinetics being zero order in each [sugar] throughout the variation. The sugar takes part in the reaction through the enediol ion $\left(\mathrm{S}^{-}\right)^{27}$.

Mechanism of $\mathrm{Ru}(\mathrm{III})$ catalysis of periodate oxidation of $\mathrm{L}(+)$ arabinose and $\mathrm{D}(+)$ galactose in aqueous alkaline medium, involves the interaction of reactive species $\left[\mathrm{RuCl}_{3}(\mathrm{OH})_{2} \cdot \mathrm{H}_{2} \mathrm{O}\right]^{2-}$ of $\mathrm{Ru}(\mathrm{III})$ and $\left[\mathrm{IO}_{4}^{-}\right]$leading to the formation of a complex, which in the rate-determining step decomposes into another complex with the release of $\mathrm{Cl}^{-}$ion ${ }^{28}$.

The kinetics of $\mathrm{Ru}(\mathrm{III})$ catalyzed oxidation of some reducing sugars viz. glucose, fructose, maltose and lactose ${ }^{29}$ by sodium metaperiodate led to the rate law:

$$
\frac{\mathrm{d}\left[\mathrm{IO}_{4}^{-}\right]}{\mathrm{dt}}=\frac{\mathrm{k}\left[\mathrm{OH}^{-}\right][\text {substrate }]\left[\mathrm{IO}_{4}^{-}\right][\text {catalyst }]}{\mathrm{k}^{\prime}+\mathrm{k}^{\prime \prime}\left[\mathrm{OH}^{-}\right]+\mathrm{k}^{\prime \prime}\left[\mathrm{OH}^{-}\right][\text {substrate }]\left[\mathrm{IO}_{4}^{-}\right]}
$$

A mechanism involving $\left[\mathrm{Ru}(\mathrm{III})-\mathrm{IO}_{4}^{-}\right]$complex has been proposed.

The oxidation of maltose by aqueous alkaline solution of periodate is zero order dependent in $\left[\mathrm{IO}_{4}^{-}\right]$and first order dependent in [maltose] and $\left[\mathrm{OH}^{-}\right]^{30}$.<smiles>[R]C(O)C=O</smiles>

(S)<smiles>[R]/C=C\O</smiles>

(E)

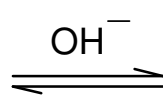<smiles>[R]/C=C\[O-]</smiles>

(E)

(glucose or galactose)

(E)<smiles>[TeH4]</smiles>

$(\mathrm{E})+\mathrm{PtCl}_{5}(\mathrm{OH})^{2-}$<smiles>C#C</smiles><smiles>O=C[CH]C(=O)OC=O</smiles>

(ii)

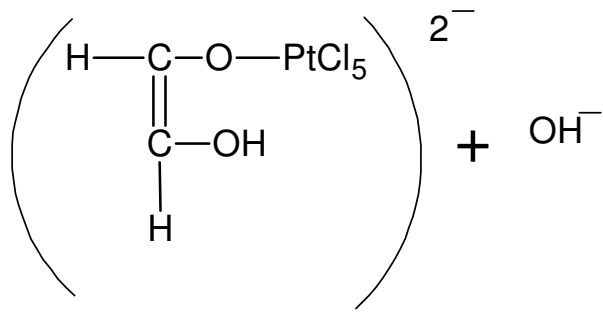

(X)

\section{(X)}
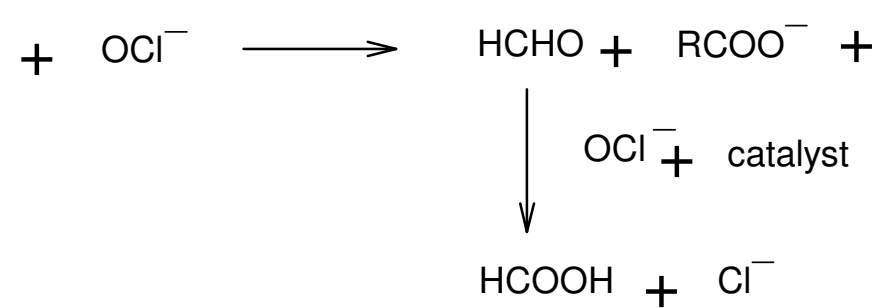

Scheme-VII 
Kinetics of oxidation of D-glucose and D-fructose by alkaline solution of potassium iodate in presence of $\mathrm{Ru}(\mathrm{III})$ as homogeneous catalyst shows first order kinetics in [Ru(III)] and zero order in [sugar] ${ }^{31}$. The proposed mechanism involves the formation of the most reactive activated complex by the interaction of $\left[\mathrm{RuCl}_{2}\left(\mathrm{H}_{2} \mathrm{O}\right)(\mathrm{OH})_{2}\right]^{2-}$ and $\mathrm{IO}_{3}{ }^{-}$species in the rate determining step.<smiles>CCOOO</smiles><smiles></smiles><smiles>[R]C1CCC[C@@H]([O-])O1</smiles>

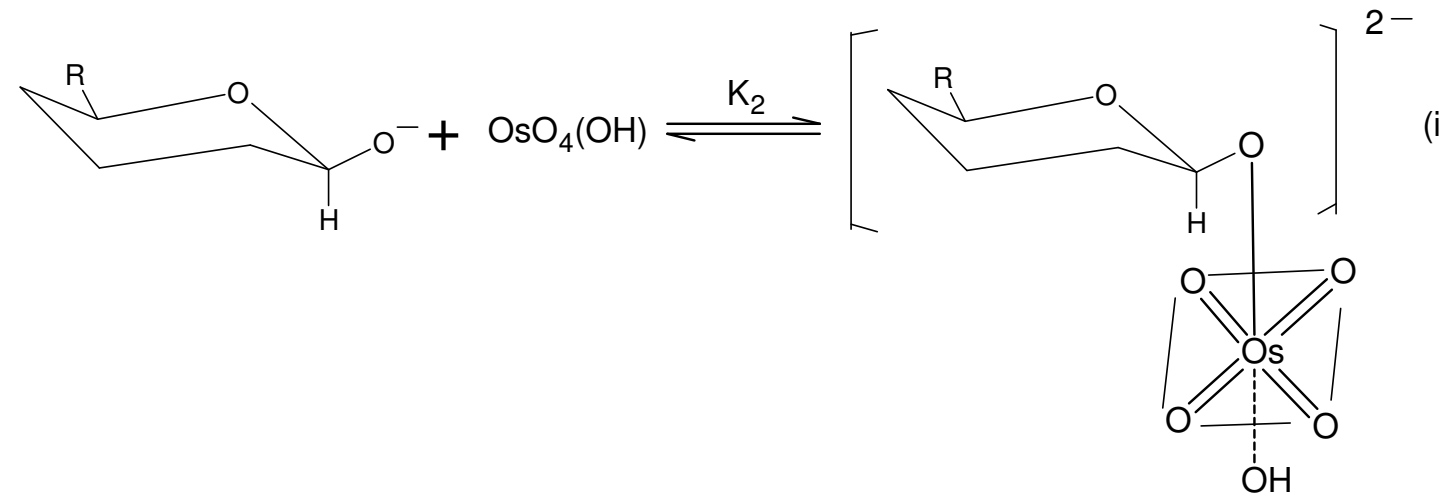
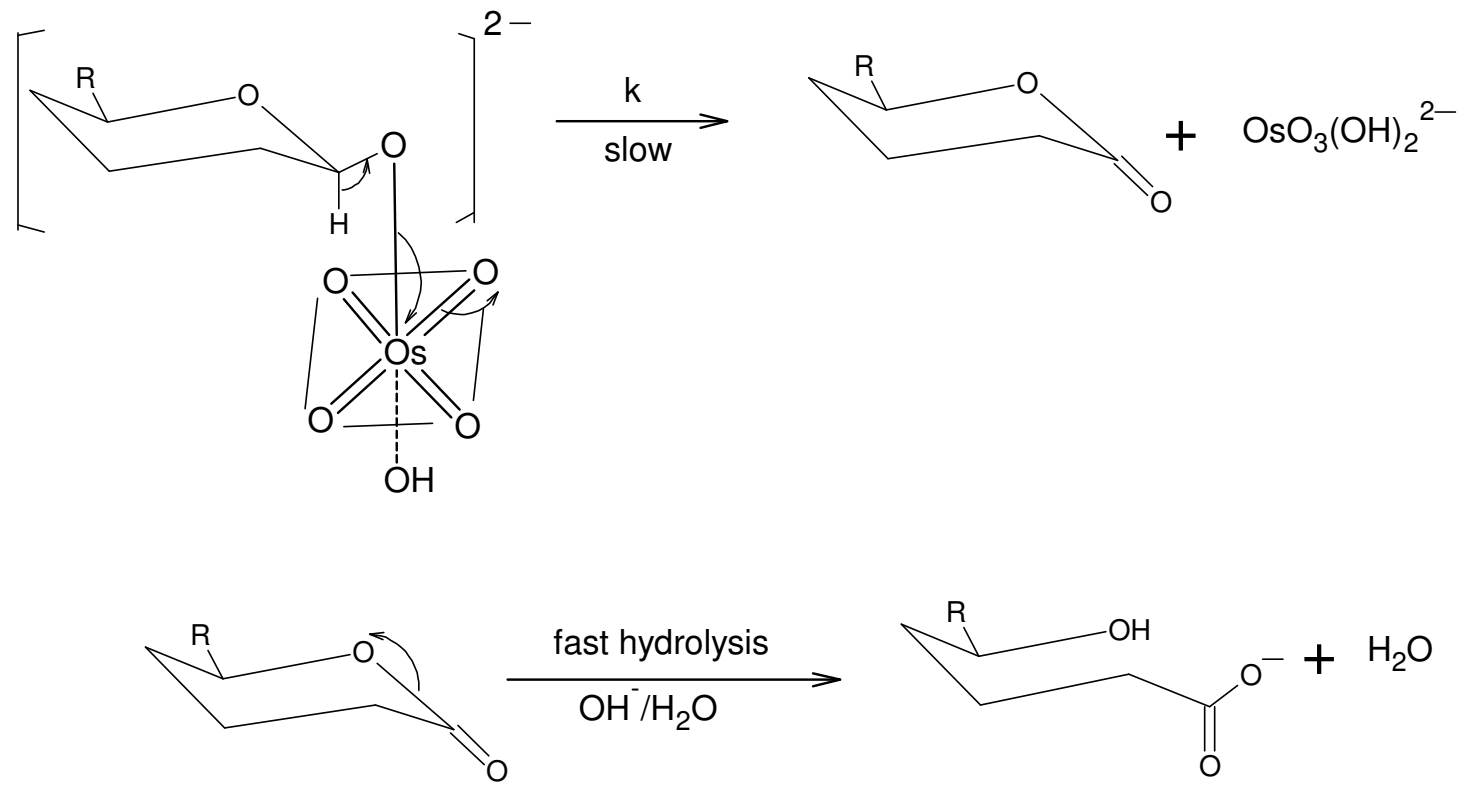

$\mathrm{R}=-\mathrm{CH}_{2} \mathrm{OH}$ for hexose

$\mathrm{R}=-\mathrm{H}$ for pentose 

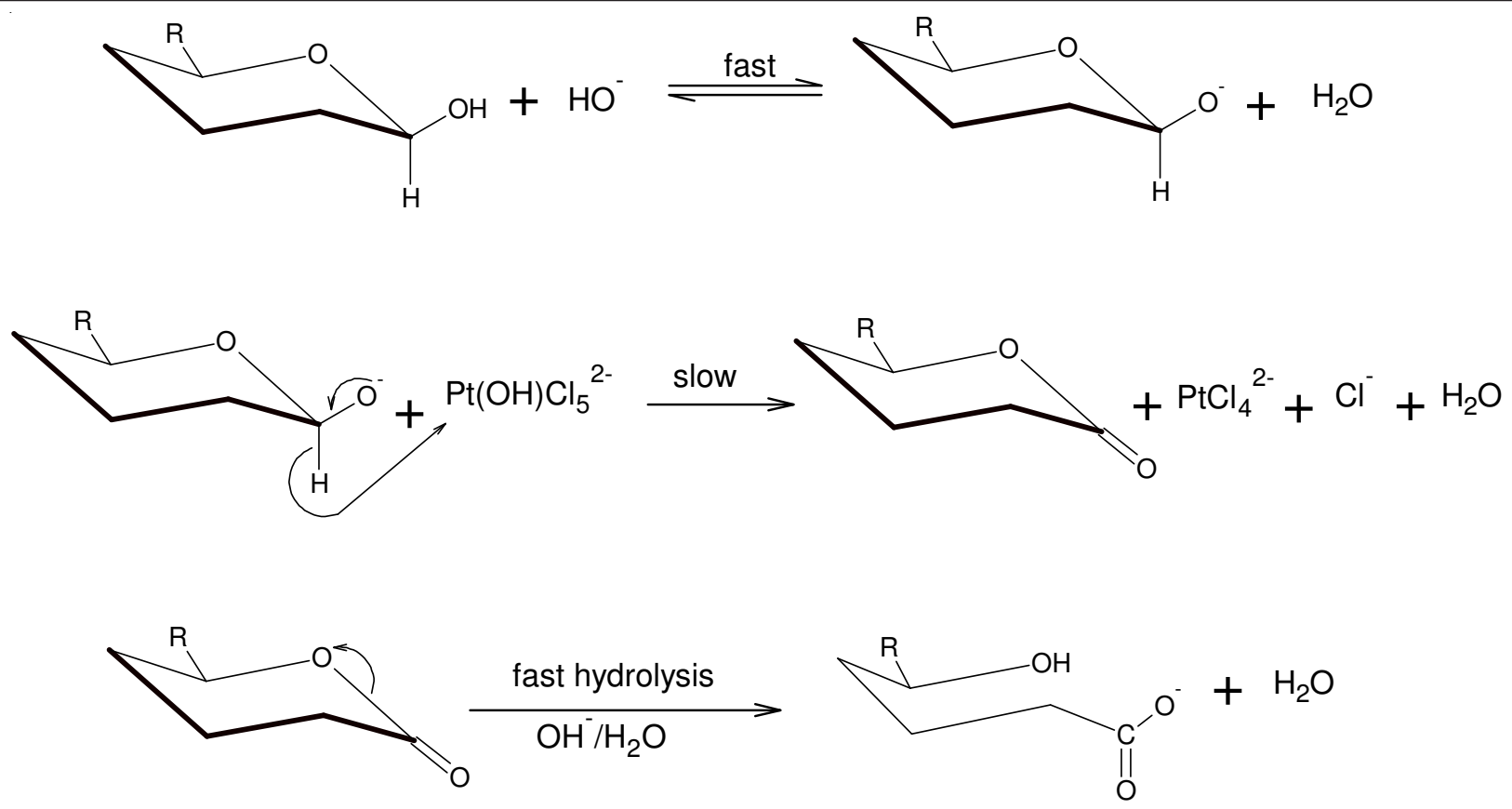

$$
\begin{aligned}
& R=-\mathrm{CH}_{2} \mathrm{OH} \text { for hexose } \\
& R=-\mathrm{H} \text { for pentose }
\end{aligned}
$$

\section{Scheme-IX}

A general mechanism for oxidizing pentoses, hexoses and disaccharides by $\mathrm{OsO}_{4}$ in alkaline medium has been proposed ${ }^{35}$. The reaction exhibit pseudo-unimolecular kinetics with respect to $\mathrm{OsO}_{4}$, are first order with respect to lower [sugar] and $\left[\mathrm{OH}^{-}\right]$but tend towards zero order with respect to both higher [sugar] and $\left[\mathrm{OH}^{-}\right]$. The results suggest the formation of an activated complex between the enediol and $\mathrm{OsO}_{4}$, which slowly disproportionates to give Os(IV) species and the intermediate products.

The kinetics of $\mathrm{Pt}(\mathrm{IV})$ catalyzed chloramine-T oxidation of glucose, galactose and fructose ${ }^{36}$ in alkaline medium have been reported to be first order in [oxidant]. The order in [substrate] and $\left[\mathrm{OH}^{-}\right]$decreases from unity to zero at higher [substrate] and $\left[\mathrm{OH}^{-}\right]$respectively. The positive effect of $\mathrm{Cl}^{-}$ at lower $\left[\mathrm{Cl}^{-}\right]$, positive effect of ionic strength and an evidence for the formation of 1:1 complex between $\mathrm{Pt}(\mathrm{IV})$ and hexose led to a mechanism (Scheme-VII).

In the $\mathrm{Ru}(111)$ catalyzed oxidation of D-mannose, Dribose and L-sorbose by chloramine- $\mathrm{T}^{37}$ and of glucose, galactose, fructose, maltose and lactose by $\mathrm{Os}(\mathrm{VIII})^{38}$ in the presence of sodium metaperiodate in alkaline medium, an evidence for the formation of 1:1 complex between substrate and catalyst $^{37}$ and Os(VIII) (oxidant) and $\operatorname{sugar}^{38}$ have been reported. The reaction kinetics of the oxidation of some aldoses, aminosugars and methylated sugars ${ }^{39}$ by Os(V1ll) in alkaline medium led to the rate law:

$$
-\frac{\mathrm{d}\left[\mathrm{OsO}_{4}(\mathrm{OH})^{-}\right]}{\mathrm{dt}}=\frac{\mathrm{kK}_{1} \mathrm{~K}_{2}[\mathrm{~S}]\left[\mathrm{OH}^{-}\right][\mathrm{Os}(\mathrm{VIII})]_{\mathrm{T}}}{1+\mathrm{K}_{1} \mathrm{~K}_{2}[\mathrm{~S}]\left[\mathrm{OH}^{-}\right]}
$$

The steps of the reactions may be expressed as shown (Scheme-VIII).
The kinetic behaviour and relative reactivities of some carbohydrates (aldoses, aminosugars and methylated sugar) towards Pt(IV) in alkaline medium have been studied ${ }^{40}$. The reaction follows the rate law:

$$
-\frac{\mathrm{d}[\mathrm{Pt}(\mathrm{IV})]}{\mathrm{dt}}=\mathrm{k}[\mathrm{Pt}(\mathrm{IV})][\text { aldose }]\left[\mathrm{OH}^{-}\right]
$$

It is believed that the anion of the aldose reacts with the oxidant to form product (Scheme-IX).

Inhibition effect of $\mathrm{PdCl}_{2}$ on the oxidation of sugars by alkaline hexacynoferrate(III) was investigated by Bajpai et al. ${ }^{41}$. The reactions are zero order in [hexacynoferrate(III)] and first order in $\left[\mathrm{OH}^{-}\right]$, while order in [sugar] decreases from unity at high concentration. Kinetic and spectrophotometric evidence support the formation of $\{\mathrm{Pd}(\mathrm{II})-($ sugar $)\}$ and $\left\{\mathrm{Pd}(\mathrm{II})-(\text { sugar })_{2}\right\}$ complex and their resistance to react with $\mathrm{Fe}(\mathrm{CN})_{6}{ }^{3-}$.

The following mechanism has been proposed in the oxidation of some aldoses like glucose, galactose, xylose and ribose $^{42}$ by hexacynoferrate $[\mathrm{HCF}(111)]$ ion in aqueous alkaline buffered medium (Scheme-X).

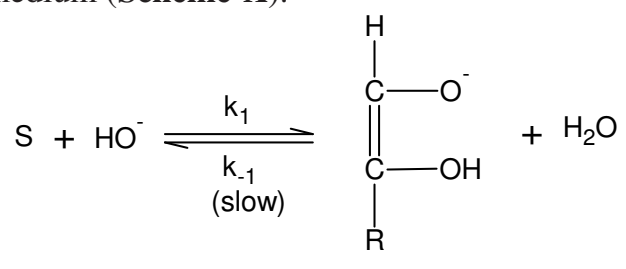

(en )

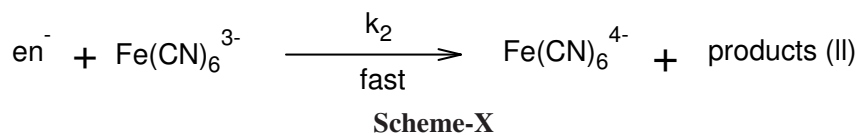


where $\mathrm{S}$ and $\mathrm{en}^{-}$represent the aldoses and intermediate enediol ion.

Based upon the proposed mechanism, the rate law is

$$
-\frac{\mathrm{d}[\mathrm{HCF}(\mathrm{III})]}{\mathrm{dt}}=\mathrm{k}_{1}[\mathrm{~S}]\left[\mathrm{OH}^{-}\right]
$$

The kinetics and mechanism of $\mathrm{Cu}$ (II) inhibition of oxidation of maltose and xylose by hexacyanoferrate(III) in alkaline buffer medium was found to be zero order in [oxidant] and $[\text { sugar }]^{43}$. The order of reaction in sugar decreased at higher sugar concentration. The rate of reaction decreased with increase in $\mathrm{Cu}$ (II) concentration. Ionic strength has no significant effect on reaction rate. Based on kinetic data following mechanism has been proposed (Scheme-XI).

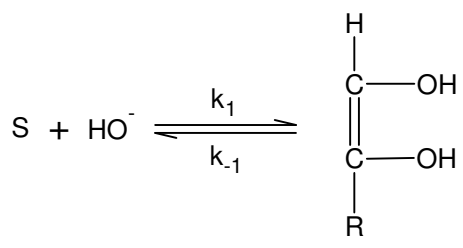

E (1,2-enediol intermediate)

$$
\begin{gathered}
\left.\mathrm{E}+\mathrm{Fe}(\mathrm{CN})_{6}{ }^{3-} \stackrel{\mathrm{k}_{2} \longrightarrow \text { Seheme-XI }}{\longrightarrow} \mathrm{FN}\right)_{6}^{4-}+\text { other products } \\
\text { Schem }
\end{gathered}
$$

Kinetics of oxidation of D-glucose, D-galactose, D-fructose, D-ribose, D-arabinose, D-xylose and 2-deoxy-D-glucose by diperiodatoargentate(III) (DPA) in alkaline medium is first order in [DPA] and $<1$ order in [sugar] over the concentration range studied ${ }^{44}$

Kinetic studies carried out for the oxidation of some monosaccharides viz., D-ribose, D-xylose, D-arabinose, Dglucose, $\mathrm{D}$-fructose, $\mathrm{D}$-galactose, 2-deoxyglucose and $\alpha$-methyl glucopyranoside by $\mathrm{MnO}_{4}^{-}$in alkaline medium have shown that the reactions follow first order kinetics both with respect to [oxidant] and [sugar $]^{45}$. A mechanism that involves the formation of a 5-membered cyclic intermediate complex between $\mathrm{MnO}_{4}{ }^{-}$ and 1,2-enediol form of the sugar has been proposed.

Oxidation of reducing sugars in acidic medium: In most earlier works and even in some most recent reports on the oxidation of reducing sugars in acidic medium, a direct attack on the free carbonyl and/or cyclic forms of the reducing sugars have been assumed.

The kinetics of the oxidation of D-fructose with vanadium $(\mathrm{V})$ in perchloric acid have been studied ${ }^{46}$. The reaction is of first order with respect to the [fructose], but the values of rate constant increase slightly with increasing $[\mathrm{V}(\mathrm{V})]$. A possible three step mechanism (Scheme-XII) involving $\mathrm{C}-\mathrm{H}$ bond fission and yielding glucosones as primary product have been suggested.

$$
\begin{aligned}
\mathrm{V}(\mathrm{V})+\mathrm{SH}^{+} & \rightleftharpoons \mathrm{C} \quad \text { (fast) } \\
\mathrm{C}+\mathrm{V}(\mathrm{V}) & \rightleftharpoons \mathrm{R}^{\prime}+\mathrm{V}^{(\mathrm{IV})}+\mathrm{H}^{+}+\mathrm{V}(\mathrm{V}) \\
\mathrm{R}^{\prime}+\mathrm{V}(\mathrm{V}) & \longrightarrow \mathrm{P}+\mathrm{V}(\mathrm{IV})+\mathrm{H}^{+} \quad \text { (fast) }
\end{aligned}
$$

where $\mathrm{C}, \mathrm{R}^{\bullet}$ and $\mathrm{P}$ represent the complex, free radical and product.

A comparison of the kinetic parameters of oxidation of monosaccharides by $\mathrm{Ce}(\mathrm{IV}), \mathrm{Cr}(\mathrm{VI})$ and $\mathrm{V}(\mathrm{V})$ have also been reported $^{47}$.

The kinetics of oxidation of pentoses and hexoses by vanadium $(\mathrm{V})^{48}$, of pentoses and hexoses ${ }^{49}$, D-erythrose and glyceraldehyde ${ }^{50}$, D-fructose and L-sorbose ${ }^{51}$ by both $\mathrm{V}(\mathrm{V})$ and $\mathrm{Cr}(\mathrm{VI})$ and of pentoses and hexoses ${ }^{52}$ by $\mathrm{Cr}(\mathrm{VI})$ in perchloric acid was shown to be first order in [oxidant] and [substrate] except for $\mathrm{V}(\mathrm{V})$ oxidation $^{51}$, where, order with respect to [substrate] is $<1$ The reactions are acid catalyzed. The radical mechanism has been proposed for $\mathrm{V}(\mathrm{V})$ oxidations ${ }^{48-51}$.

Kinetics of oxidation of D-maltose by quinquevalent vanadium in aqueous sulfuric acid medium exhibit first order dependence each in [oxidant] and [substrate] ${ }^{53}$.

The oxidative degradation of $\mathrm{D}$-fructose by $\mathrm{V}(\mathrm{V})$ in the presence of $\mathrm{H}_{2} \mathrm{SO}_{4}$ has an induction period followed by auto acceleration and a free radical mechanism operate during the course of the reaction ${ }^{54}$.

The kinetics of oxidation of lactose by vanadium(V) in sulfuric acid, perchloric acid and hydrochloric acid have been studied $^{55}$. The reaction is of first order both with respect to [oxidant] and [substrate]. The acid catlyzed reaction have complex dependency on acidity.

Kinetics of oxidation of D-arabinose and D-xylose by acidic solution of vanadium(V) ions in presence of $\mathrm{Mn}(\mathrm{II})$ shows first order dependence on [sugar] and $\left[\mathrm{H}^{+}\right]$at low concentration and zero order dependence on [sugar] and $\left[\mathrm{H}^{+}\right]$at high concentration $^{56}$. First order kinetics with respect to $[\mathrm{Mn}]$ also observed throughout the oxidation. The effect of $\left[\mathrm{Cl}^{-}\right]$was negligible and the rate increase with the ionic strength. A reaction mechanism involving complex formation between [sugar], [V(V)] and Mn(II) has been proposed (Scheme-XIII).

The kinetics of oxidation of sugar and sugar alcohol by $\mathrm{V}_{2} \mathrm{O}_{5}$ in acidic medium showed that each reaction was first order with respect to the substrate and oxidant ${ }^{57}$. The reaction rates were enhanced by increase in temperature, $\mathrm{pH}$, ionic strength and substrate concentration and reaction rate decreased with increase in $\mathrm{V}_{2} \mathrm{O}_{5}$ concentration with the exception of fructose which showed significant increase in reaction rates. The mechanism of the reaction involved the formation of $1: 1$ intermediate complex (Scheme-XIV) and the order of reactivities was maltose $>$ fructose $>$ sucrose $>$ glucose $>$ sorbitol $>$ mannitol.

The kinetics of the $\mathrm{Cu}(\mathrm{II})$ oxidation of D-galactose $\mathrm{e}^{58}$ and $\mathrm{D}$-glucose $\mathrm{e}^{59}$ in acetate buffers have been reported. The results have been discussed in terms of a possible mechanism of oxidation of sugar by $\mathrm{CuOAc}^{+}$present in the solution.

Electrically generated manganese(III) sulfate has been employed for the oxidation of aldopentose ${ }^{60}$, aldohexose and ketohexose $^{61}$ and 6-deoxyhexose ${ }^{62}$ in acidic medium. A first order dependence was observed on [oxidant] and on [reducing sugar]. Proposed oxidation mechanism involves the formation of enediol from sugar which reacts with $\mathrm{Mn}(\mathrm{III})$ in a rate limiting step.

Kinetics of oxidation of some aldoses by cerium(IV) in sulfuric acid medium have been reported ${ }^{63}$. The reactions are first order with respect to the cation and aldose concentration. 


$$
\mathrm{VO}_{3}^{-}+2 \mathrm{H}^{+} \rightleftharpoons \mathrm{VO}_{2}^{+}+\mathrm{H}_{2} \mathrm{O}
$$<smiles>[R]/C(O)=C/O</smiles><smiles>[R]C(O)[CH+]O</smiles>

or $\mathrm{SH}^{+}$

$$
\mathrm{R}=\mathrm{C}_{3} \mathrm{H}_{7} \mathrm{O}_{3}
$$<smiles>[R]C(O)[C+]([2H])O</smiles><smiles>[R]C(O)C(C)O[AlH2]</smiles>

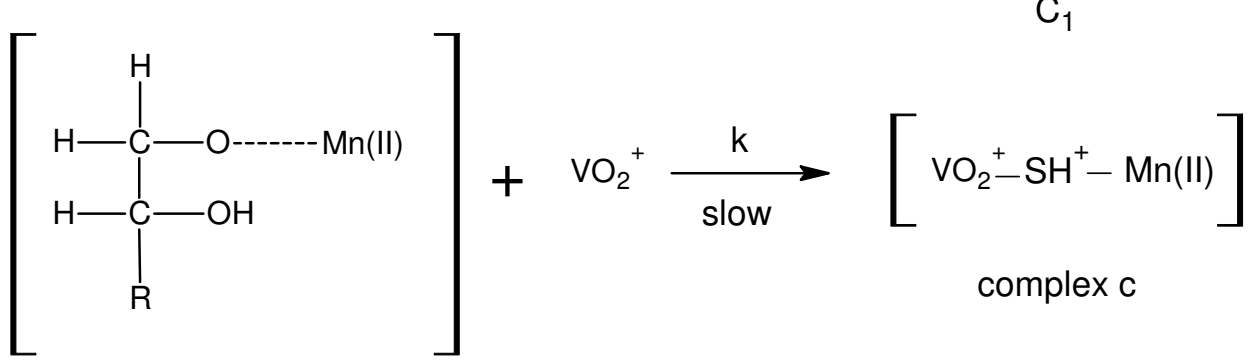

$\mathrm{C}_{1}$

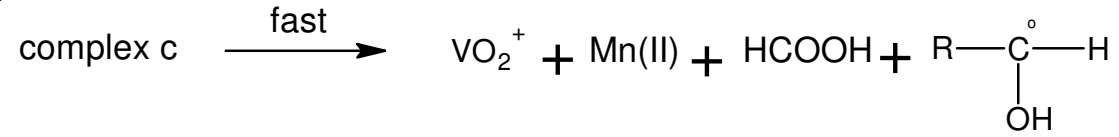

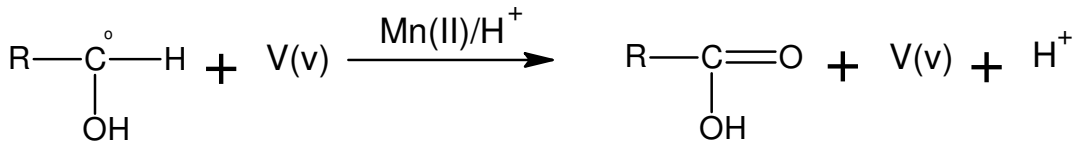

Scheme-XIII

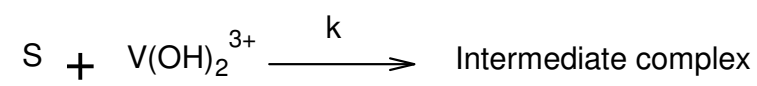

Intermediate complex $\stackrel{\mathrm{k}}{\longrightarrow}$ lactone $+\mathrm{CH}_{2} \mathrm{OH}+\mathrm{V}(\mathrm{v})$
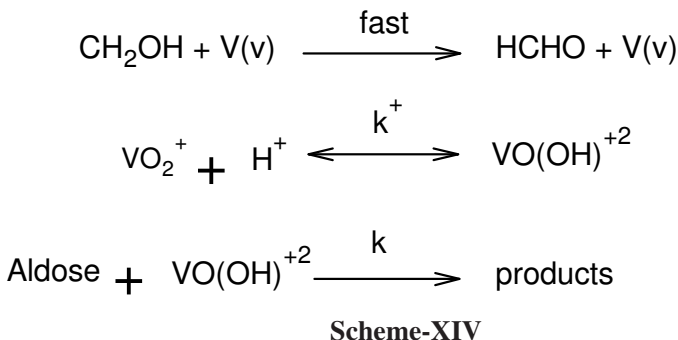

The formation of a radical as the rate-determining step has been proposed.

Hexoses and pentoses are oxidized by Ce(IV) via formation of two complex intermediates in perchloric acid. The first is partly oxidized following Michaelis-Menten kinetics and partly dissociated to the second, which is oxidized more slowly than the former ${ }^{64}$. $\mathrm{Ce}(\mathrm{IV})$ oxidized mannitol to an aldehyde in sulfuric acid medium ${ }^{65}$. The formation of an intermediate complex of the substrate with oxidant has been observed both kinetically and spectrophotometrically.

Bromide catalyzed oxidation of dextrose ${ }^{66}$, fructose ${ }^{67}$, D-mannose ${ }^{68}$, L-sorbose $^{69}$, melibiose and cellobiose ${ }^{70}$ by $\mathrm{Ce}(\mathrm{IV})$ in aqueous sulfuric acid showed first order dependence each in [sugar] and [Ce(IV)]. 
The kinetics of oxidation of D-glucose, D-galactose and $\mathrm{D}$-mannose by $t$-butyl hypochlorite in aqueous acetic acid medium shows first order kinetics in $[t-\mathrm{BuOCl}]$, fractional order in [hexose] and zero order in $\left[\mathrm{H}^{+}\right]$. Competitive mechanism involving substrate independent and dependent pathways has been proposed ${ }^{71}$.

The oxidation of aldoses by hexachloroiridate(IV) $)^{72,73}$ and tetrachloroaurate(III) $)^{72,74}$ in hydrochloric acid led to the corresponding aldonic acids or aldolactones. Kinetic parameters suggested the formation of a free radical intermediate by fission of the anomeric $\mathrm{C}-\mathrm{H}$ bond followed by the conversion of radical to the products. The oxidation of D-erythrose by hexachloroiridate(lV) is shown in Scheme-XV.

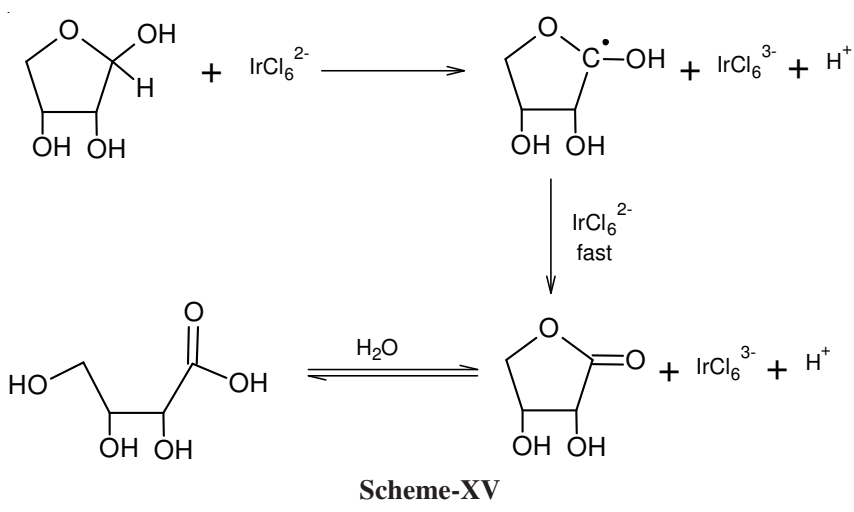

The oxidation mechanism of some aldoses and amino sugars by potassium bromate in hydrochloric acid medium proceed through the intermediate formation of bromate esters followed by the decomposition of the esters to give products ${ }^{75}$ (Scheme-XVI).

$\mathrm{Ru}(\mathrm{III})$ catalyzed oxidation of maltose ${ }^{76}$, xylose $^{77}$, galactose $^{78}, \mathrm{Rh}$ (III) catalyzed oxidation of mannitol ${ }^{79}$ and $\mathrm{Ir}(\mathrm{III})$ catalyzed oxidation of D-galactose ${ }^{80}$ by acidic solution of potassium bromate in presence of mercuric acetate as a scavenger for $\mathrm{Br}^{-}$have been carried out.

The kinetics of Pd(II) catalyzed oxidation of some reducing sugars viz. D-arabinose, D-xylose, D-galactose ${ }^{81}$, D-glucose, L-sorbose ${ }^{82}$, D-fructose and D-mannose ${ }^{83}$ by $\mathrm{N}$-bromosuccinimide in acidic medium in the presence of mercuric acetate have been reported by Singh et al. The reactions follow almost identical kinetics showing first order dependence on oxidant and substrate at low concentration, tends to zero at high concentration. Insignificant effect of $\mathrm{Hg}(\mathrm{OAc})_{2}$ was observed on reaction rate. The corresponding acids were identified as the oxidation products.

$\mathrm{Rh}$ (III) catalyzed N-bromosuccinimide oxidation of maltose and galactose ${ }^{84}$ exihibited first order dependence on [NBS], [Rh(III)] [sugar] and $\left[\mathrm{H}^{+}\right]$. Negligible effect of variation of $[\mathrm{Hg}(\mathrm{III})],\left[\mathrm{Cl}^{-}\right]$and $[$succinimide] on the rate of reaction for each sugar was observed. A reaction mechanism showing the formation of the most reactive activated complex<smiles>O=C1CCC(=P)C1</smiles>

by the interaction of a charged<smiles>[R]C[C@@H]1[C@@H](O)O[C@H](C[R])[C@@H]([R])[C@H]1[R]</smiles>

$[\mathrm{R}=\mathrm{OH}, \beta-\mathrm{D}(+)$ glucopyranose $]$

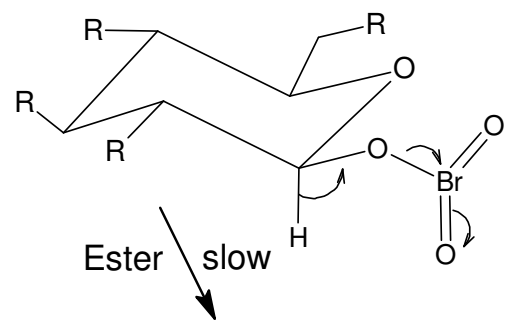

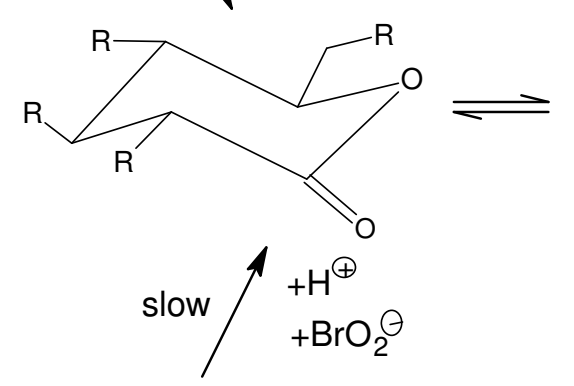<smiles>[R]CC(O)C(C(=O)O)C([R])C([R])C</smiles>

(gluconic acid)<smiles>[R]CC1O[C@H](O)[C@@H](O)[C@@H]([R])[C@@H]1[R]</smiles>

$[\mathrm{R}=\mathrm{OH}, \alpha-\mathrm{D}(+)$ glucopyranose $]$ fast

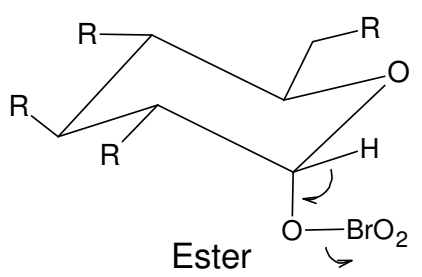

Scheme-XVI 


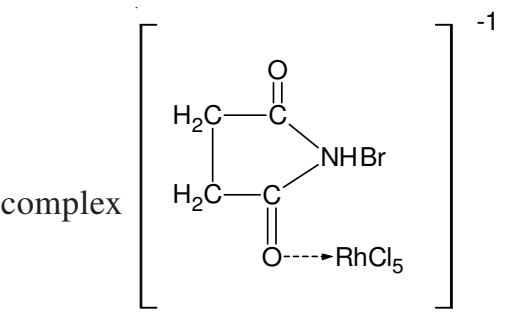

and a neutral substrate

molecule have been proposed.

The following reaction mechanism (Scheme-XVII) has been suggested for the Ir(III) catalyzed oxidation of maltose and lactose $\mathrm{e}^{85}$, melibiose and cellobiose ${ }^{86}$ by N-bromosuccinimide (NBS) in acidic medium in presence of $\mathrm{Hg}(\mathrm{OAc})_{2}$ as scavenger for $\mathrm{Br}^{-}$.

$$
\begin{aligned}
& \mathrm{NBS}+\mathrm{H}_{2} \mathrm{O} \stackrel{\mathrm{k}_{1}}{\rightleftharpoons} \mathrm{NHS}+\mathrm{HOBr} \\
& {\left[\mathrm{IrCl}_{6}\right]^{3-}+\mathrm{H}_{2} \mathrm{O} \underset{\mathrm{k}_{3}}{\stackrel{\mathrm{k}_{2}}{\rightleftharpoons}}\left[\operatorname{lrCl}_{5}\left(\mathrm{H}_{2} \mathrm{O}\right)\right]^{2-}+\mathrm{Cl}^{-}} \\
& \mathrm{HOBr}+\left[\mathrm{IrCl}_{5}\left(\mathrm{H}_{2} \mathrm{O}\right)\right]^{2-} \stackrel{\mathrm{k}_{3}}{\rightleftharpoons}\left[\operatorname{IrCl}_{5}(\mathrm{OH}) \mathrm{HOBr}\right]^{3-}+\mathrm{H}^{+} \\
& {\left[\mathrm{IrCl}_{5}(\mathrm{OH}) \mathrm{HOBr}\right]^{3-} \stackrel{\mathrm{k}}{\longrightarrow}\left[\mathrm{IrCl}_{5} \mathrm{OBr}\right]^{3-}+\mathrm{H}_{2} \mathrm{O}} \\
& \text { slow and rate determining step } \\
& \begin{aligned}
{\left[\mathrm{IrCl}_{5} \mathrm{OBr}\right]^{3-}+\mathrm{S} } & \rightleftharpoons\left[\mathrm{IrCl}_{5} \mathrm{~S}\right]^{2-}+\mathrm{OBr}^{-} \\
{\left[\mathrm{IrCl}_{5} \mathrm{~S}\right]^{2-} } & \left.\rightleftharpoons \mathrm{IrCl}_{5} \mathrm{H}\right]^{3-}+\mathrm{S}^{+} \\
\mathrm{S}^{+}+\mathrm{H}_{2} \mathrm{O} & \longrightarrow \text { products } \\
{\left[\mathrm{IrCl}_{5} \mathrm{HH}\right]^{3-}+\mathrm{HOBr} } & \longrightarrow\left[\mathrm{IrCl}_{5}\left(\mathrm{H}_{2} \mathrm{O}\right)\right]^{2-}+\mathrm{Br}^{-}
\end{aligned}
\end{aligned}
$$

where S stands for sugars

Scheme-XVII
$\mathrm{Ru}(\mathrm{III})$ and $\mathrm{Ir}(\mathrm{III})$ catalyzed and uncatalyzed oxidation of D-glucose (S) by N-bromosuccinimide (NBS) in presence of sulphuric acid, $\mathrm{KCl}$, mercuric acetate and acetic acid have been investigated ${ }^{87}$. The first order dependence on [NBS] as well as [S] in the uncatalyzed reaction is suggestive of a mechanism shown in Scheme-XVIII.

On the other hand, first order dependence in [NBS], fractional order each in [S] and [Ru(III)/Ir(III)] and ability of the metal to form complex with organic substrates and highly enhanced rates in the catalyzed reaction led to the formation of $\mathrm{Ru}(\mathrm{III})-\mathrm{S} / \mathrm{Ir}(\mathrm{III})-\mathrm{S}$ complex which slowly reacts with NBS in rate determining step to give products (Scheme-XIX).

$$
\begin{aligned}
& \text { NBS } \mathrm{H}^{+} \rightleftharpoons \mathrm{K} \rightleftharpoons \mathrm{N}^{+} \mathrm{BSH} \\
& \mathrm{Ru}^{\mathrm{III}}+\mathrm{S} \stackrel{\mathrm{K}_{1}}{\rightleftharpoons}\left[\mathrm{Ru} \mathrm{u}^{\mathrm{II}}-\mathrm{S}\right] \text { complex } \\
& {\left[R u^{\prime \prime \prime}-S\right]+N B S \underset{\text { slow }}{\stackrel{k}{\longrightarrow}}\left[\mathrm{Ru}^{\mathrm{v}}-\mathrm{S}\right]} \\
& {\left[\mathrm{Ru} \mathrm{v}^{\mathrm{v}}-\mathrm{S}\right] \stackrel{\text { fast }}{\longrightarrow} \delta \text {-Lactone of aldonic acid }+} \\
& \mathrm{HBr}+\mathrm{Ru}{ }^{\prime \prime \prime}+\mathrm{NH}\left(\mathrm{CH}_{2} \mathrm{CO}\right)_{2} \\
& \text { Scheme-XIX }
\end{aligned}
$$

The rate law for $\mathrm{Pd}(\mathrm{II})$ catalyzed oxidation of xylose and lactose ${ }^{88}$ by N-bromoacetamide (NBA) in acidic medium in the presence of mercuric acetate may be written as:

$$
\text { rate }=\frac{\mathrm{k}\left[\mathrm{PdCl}_{4}\right]^{2-}[\mathrm{L}][\mathrm{NBA}]_{\mathrm{T}}[\mathrm{Hg}(\mathrm{II})]_{\mathrm{T}}}{[\mathrm{H}+]\left\{\mathrm{k}_{-1}\left(1+\mathrm{k}_{1}[\mathrm{NBA}]\right)+\mathrm{k}_{1}[\mathrm{Hg}(\mathrm{II})]_{\mathrm{T}}\right\}}
$$

where L stands for xylose and lactose.<smiles>C[C@H]1O[C@@H](CO)[C@@H](O)[C@H](O)[C@H]1O</smiles>

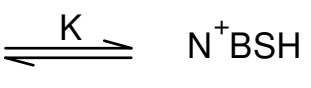<smiles></smiles>

$\delta$-Lactone of gluconic acid
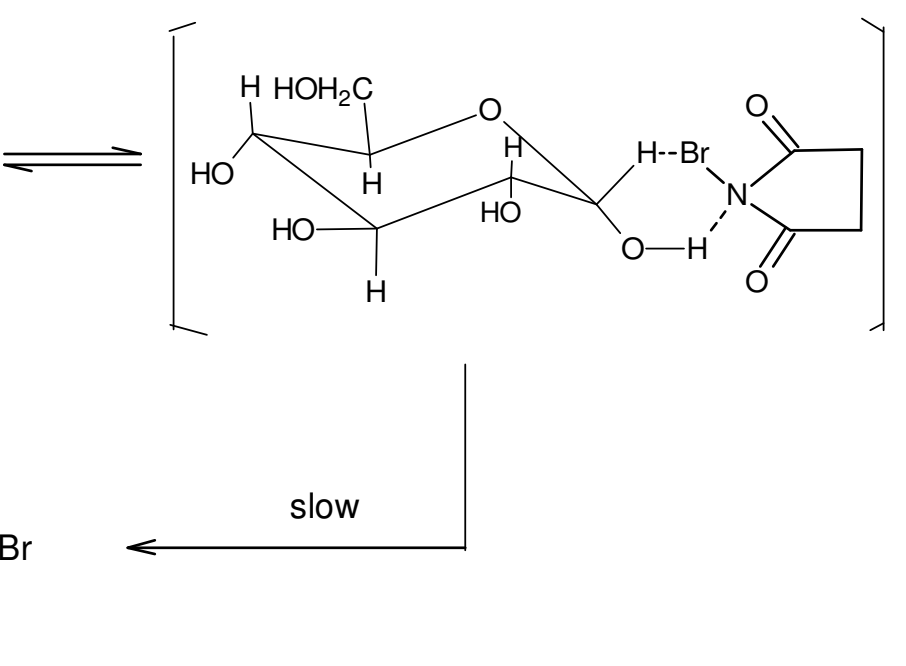
$\mathrm{N}$-Bromoacetamide and $\left[\mathrm{PdCl}_{4}\right]^{2-}$ has been reported as oxidizing and catalytic species.

In the $\mathrm{Rh}(\mathrm{III})$ catalyzed oxidation of maltose and lactose ${ }^{89}$ by $\mathrm{N}$-bromoacetamide in presence of perchloric acid and using mercuric acetate as $\mathrm{Br}^{-}$scavenger, a mechanism showing the formation of most reactive activated complex $\left[\mathrm{RhCl}_{4}\left(\mathrm{H}_{3} \mathrm{O}\right) \mathrm{H}_{2} \mathrm{OBr}\right]^{+}$ and unreactive complex $\left[\mathrm{RhCl}_{4}\left(\mathrm{H}_{2} \mathrm{O}\right)\left(\mathrm{H}_{2} \mathrm{OBrHg}\right)\right]^{2+}$ has been proposed. The kinetics of oxidation of melibiose and cellobiose ${ }^{90}$ by N-bromoacetamide (NBA) in the presence of $\mathrm{Rh}(\mathrm{III})$ chloride as homogeneous catalyst in acidic medium shows first order kinetics with respect to [NBA], [Rh(III)] and [substrate]. The rate is proportional to $\left[\mathrm{H}^{+}\right]$. No effect of $[\mathrm{Hg}(\mathrm{III})]$ [NHA] or $\left[\mathrm{Cl}^{-}\right]$and little effect of ionic strength and dielectric constant on the rate was observed. The rate-determining path gives an activated complex by the interaction of charged complex species and neutral sugar molecule, which in the subsequent steps disproportionate into the reaction products with the regeneration of catalyst.

The kinetics and mechanism of Ru(III)-catalyzed and $\mathrm{Hg}$ (II)-co-catalyzed oxidation of D-galactose and D-ribose ${ }^{91}$, D-arabinose and D-mannose ${ }^{92}, \mathrm{D}$-glucose and cellobiose ${ }^{93}$, $\mathrm{Ir}(\mathrm{III})$-catalyzed and $\mathrm{Hg}$ (II)-co-catalyzed oxidation of Dglucose and D-fructose ${ }^{94}, \mathrm{Pd}(\mathrm{II})$ catalyzed and $\mathrm{Hg}(\mathrm{II})$ cocatalyzed oxidation of D-arabinose and ribose ${ }^{95}$, D-glucose and D-fructose ${ }^{96} \mathrm{D}$-mannose and D-maltose ${ }^{97}$ and D-melibiose $^{98}$ by $\mathrm{N}$-bromoacetamide in acidic medium have been recently reported.

The oxidation of monosaccharides with bromamine-T was also carried out in hydrochloric acid solution ${ }^{99}$. Kinetic parameters revealed that a low reactivity of ketoses relative to aldoses and indicated that cyclic form of the latter are involved in the oxidations.

Kinetic investigations on $\mathrm{Pd}(\mathrm{II})$ ) catalyzed oxidation of D-fructose by acidic solution of chloramine-T in presence of mercuric acetate, as scavenger shows first order kinetics in [chloramine-T], [Pd(II)] and zero order in [substrate $]^{100}$. Increase in $\left[\mathrm{Cl}^{-}\right]$showed positive effect while $\left[\mathrm{H}^{+}\right]$showed zero effect. Negligible effect of mercuric acetate and ionic strength was observed. A transient complex, formed between $\mathrm{PdCl}_{2}$ and chloramine- $\mathrm{T}$ disproportionates in a slow and rate determing step.

$\mathrm{Rh}(\mathrm{III})$ catalyzed oxidation of dextrose and maltose $\mathrm{e}^{101}$ and sucrose ${ }^{102}$ by sodium periodate in acidic medium has been studied in presence of mercuric acetate as scavenger for $\mathrm{Br}^{-}$. The rate shows first order kinetics with respect to oxidant, sodium periodate and $\mathrm{Rh}(\mathrm{III})$ for each sugar.

The relative reactivities and kinetic behaviour of some aldoses, amino sugars and methylated sugars towards permanganate in perchloric acid medium showed that the oxidation of the hemiacetal to the corresponding lactone is facile ${ }^{103}$.

Oxidation kinetics of aldoses and ketoses by $\mathrm{Mn}$ (III) in sulfuric acid medium have been reported ${ }^{104}$.

The kinetics and mechanism of oxidation of D-ribose, D-glucose and D-fructose by dichloroisocyanuric acid in aqueous acetic acid-perchloric acid mixture catalyzed by $\mathrm{Ru}(\mathrm{III})$ have been investigated recently. The oxidation of D-ribose and $\mathrm{D}$-glucose is first order in [oxidant] and in [Ru(III)] and zero order in [substrate] and in $\left[\mathrm{H}^{+}\right]$whereas the fructose exhibits zero order in [oxidant], first order in [catalyst] and zero order in [substrate] and in $\left[\mathrm{H}^{+}\right]$. It is assumed that the $\beta$-anomer in all cases reacts with $\mathrm{Ru}(\mathrm{V})$ or $\mathrm{Ru}(\mathrm{III})$ to yield products ${ }^{105}$.

Miscellaneous oxidation: Some other oxidation studies with different oxidant under different reaction conditions are mentioned below:

Kinetics of potassium hexacynoferrate catalyzed oxidation of D-glucose with ammonium persulphate exhibit zero order dependence in [glucose] and 0.5 (at low concentration) to 0 (at high conc.) in [hexacynoferrate(III) $]^{106}$. The study of Mn(III) catalyzed oxidation of glucose by persulfate ion showed that the process occurs via chain radical mechanism ${ }^{107}$.

Mechanistic studies on oxidation of arabinose, fructose and lactose by peroxydisulphate have been reported. The reactions are first order in peroxydisulphate and of fractional order in substrate concentration ${ }^{108}$.

In the kinetic studies on the oxidation of D-maltose by aquasulfato $\mathrm{Ce}(\mathrm{IV})$ complex, the rate determining step is the formation of free radicals from the hydrolyzed substrate molecule ${ }^{109}$.

$\mathrm{Ru}(\mathrm{III})$ catalyzed oxidation of aldoses by N-bromosuccinimide (NBS) under acidic ${ }^{110}$ and basic ${ }^{111}$ conditions have been studied.

The order of reactivity of some pentoses and hexoses has been determined for their oxidation by NBS in aqueous acidic media containing $\mathrm{Hg}$ (II) acetate. Based on kinetic measurements, mechanism for the reaction has been suggested ${ }^{112}$.

Kinetic parameters for the oxidation of D-ribose, 2-deoxyD-ribose and nucleotides by $\mathrm{Ru}\left(\right.$ tpy)(bpy) $\mathrm{O}_{2}{ }^{+}$[tpy $=2,2^{\prime}, 2^{\prime \prime}-$ terpyridine, bpy $=2,2^{\prime}$-bypyridine] have been determined in the phosphate buffer ${ }^{113}(\mathrm{pH}=7)$.

The kinetics of electron transfer reaction of iron(III) perchlorate with D-xylose, D-arabinose and D-ribose ${ }^{114}$ and with D-glucose, D-galactose and D-mannose ${ }^{115}$ has been studied in the presence of 2,2'-bipyridyl. The formation of $1: 2$ complex between iron(III) and bipyridyl which reacts with substrate to form an intermediate complex has been suggested. This complex disproportionates in a slow step to form product by a free radical mechanism. The oxidation of a aldohexose molecule is shown in Scheme-XX.

The results of the oxidation of D-galactose by $\mathrm{Cu}(\mathrm{II})$ in acetate-acetic acid buffers confirm that $\mathrm{CuOAc}^{+}$is the reactive species $^{116}$.

The reactivity of D-glucose-1-phosphate towards hexachloroiridate(IV) has been studied in sodium acetateacetic acid buffer ${ }^{117}$. The reaction is first order each in [iridium(IV)] and [glucose-1-phosphate]. The reaction is believed to occur through the intermediate formation of 1:1 complex between hexachloroiridate(IV) and glucose-1-phosphate followed by the decomposition of the complex (Scheme-XXI).

The kinetics of oxidation of some aldoses and aldose phosphate by $\mathrm{Au}(\mathrm{III})$ in sodium acetate-acetic acid buffer medium have been reported ${ }^{118}$. The reactions are first order with respect to $[\mathrm{Au}(\mathrm{III})]$ and [substrate]. The reaction appear to involve different $\mathrm{Au}(\mathrm{III})$ species viz. $\mathrm{AuCl}_{4}^{-}, \mathrm{AuCl}_{3}\left(\mathrm{OH}_{2}\right)$ and $\mathrm{AuCl}_{3}(\mathrm{OH})^{-}$. The results are interpreted in terms of the probable intermediate formation of free radicals and $\mathrm{Au}(\mathrm{II})$. The oxidation of Dglucose-6-phosphate is shown in Scheme-XXII). 


$$
\begin{aligned}
& {\left[\mathrm{Fe}\left(\mathrm{H}_{2} \mathrm{O}\right)_{6}\right]^{+3}+2 \mathrm{BipyH}^{+} \stackrel{\mathrm{k}_{1}}{\rightleftharpoons}\left[\mathrm{Fe}\left(\mathrm{H}_{2} \mathrm{O}\right)_{2}(\mathrm{Bipy})_{2}\right]^{+3}+2 \mathrm{H}^{+}+4 \mathrm{H}_{2} \mathrm{O}} \\
& {\left[\mathrm{Fe}\left(\mathrm{H}_{2} \mathrm{O}\right)_{2}(\mathrm{Bipy})_{2}\right]^{+3}+\mathrm{C}_{6} \mathrm{H}_{12} \mathrm{O}_{6} \stackrel{\mathrm{k}_{2}}{\rightleftharpoons} \text { complex } \underset{\text { slow }}{\stackrel{\mathrm{k}}{\rightleftharpoons}}} \\
& { }^{\circ} \mathrm{CHOH}(\mathrm{CHOH})_{3} \mathrm{CH}_{2} \mathrm{OH}+\mathrm{HCOOH}+\left[\mathrm{Fe}\left(\mathrm{H}_{2} \mathrm{O}\right)_{2}(\mathrm{Bipy})_{2}\right]^{+2}+\mathrm{H}^{+}
\end{aligned}
$$

${ }^{-} \mathrm{CHOH}(\mathrm{CHOH})_{3} \mathrm{CH}_{2} \mathrm{OH}+\mathrm{Fe}^{3+} \stackrel{\text { fast }}{\longrightarrow} \mathrm{CHO}(\mathrm{CHOH})_{3} \mathrm{CH}_{2} \mathrm{OH}+\mathrm{Fe}^{2+}+\mathrm{H}^{+}$

\section{Scheme-XX}

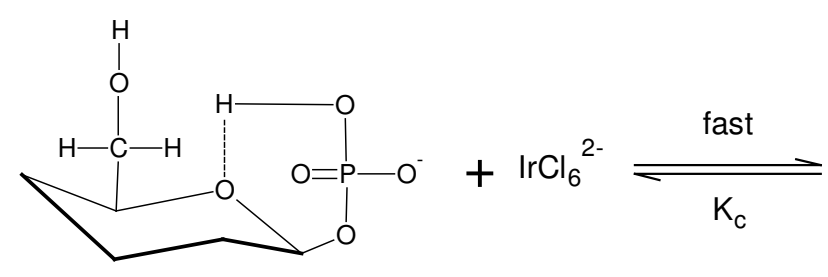

$\beta$-pyranose

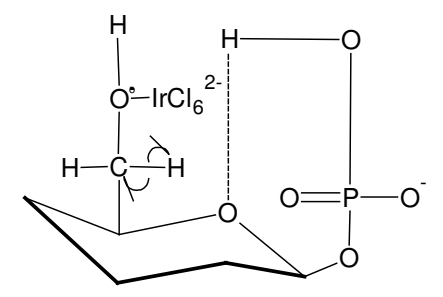

Intermediate Complex

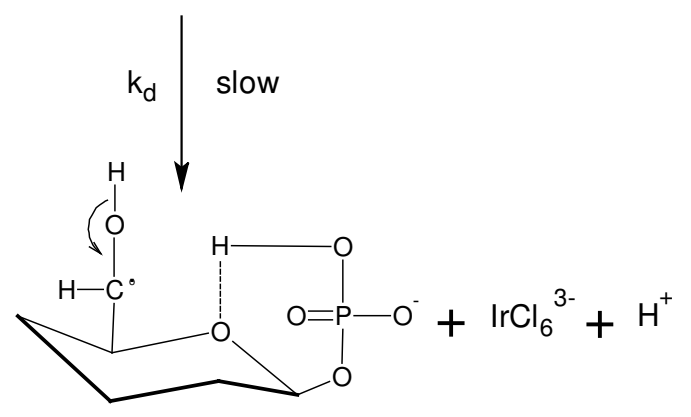

free-radical Intermediate

Scheme-XXI

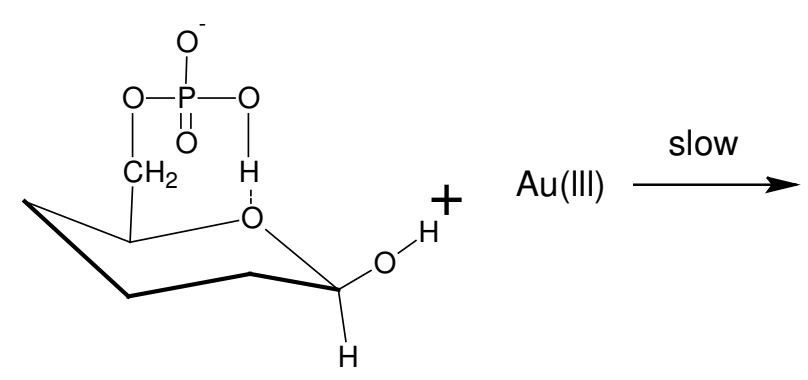

D-glucose 6-phosphate

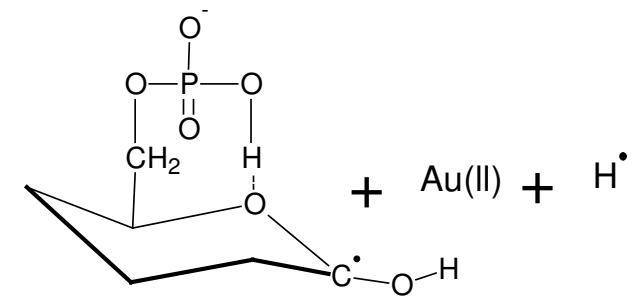

$\mathrm{Au}$ (III) oxidation followed by hydrolysis (fast)

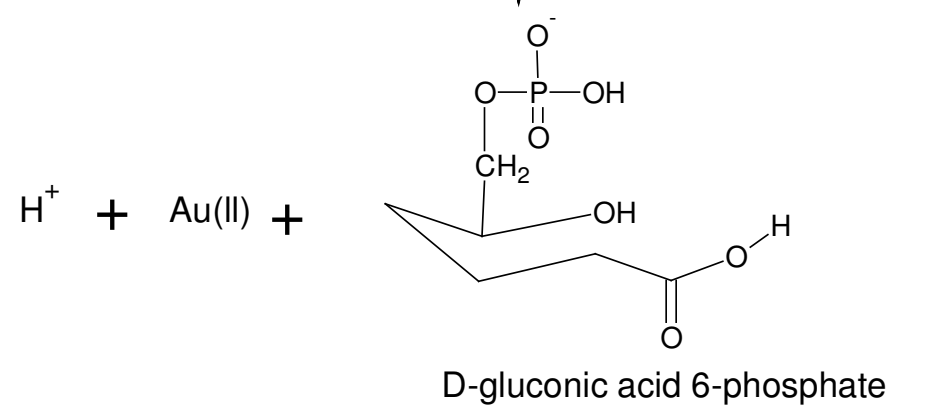


The kinetics of the oxidation of sugars in alkaline potassium permanganate and chromic acid media have been reported recently ${ }^{119}$. The effect of ionic strength, $\mathrm{pH}$, sugar concentration and temperature have been investigated kinetically.

The rate of oxidation of fructose, sucrose and maltose by $\mathrm{KMnO}_{4}$ in alkaline buffer and of fructose and sucrose by hexachloro-iridate(IV) in acidic buffer follow the order maltose $\approx$ fructose $\approx$ sucrose and increase with $\mathrm{pH}$ in both acidic and alkaline media ${ }^{120}$. Each oxidation reaction is first order with respect to oxidant and sugar concentration. The results have been interpreted on the formation of 1:1 intermediate complex.

The kinetics and mechanism of oxidation of some aldoses (D-glucose and D-mannose) and corresponding alditols (D-sorbitol and D-mannitol) by $\mathrm{KMnO}_{4}$ in $\mathrm{NaHCO}_{3} / \mathrm{NaOH}$ buffer and by $\mathrm{IrCl}_{6}{ }^{2-}$ in $\mathrm{CH}_{3} \mathrm{COONa} / \mathrm{CH}_{3} \mathrm{COOH}$ buffer showed that each reaction was first order with respect to the substrate and oxidant and the reaction rate increases with increase in $\mathrm{pH}$ and salt concentration ${ }^{121}$. The reactions involve the formation of free radicals through 1:1 intermediate complex, except the oxidation of $\mathrm{D}$-mannitol by alkaline $\mathrm{KMnO}_{4}$ where the reaction proceed by the formation of a transition state.

The kinetic studies on oxidation of some simple reducing sugars $^{122}$ (glucose, galactose, fructose, maltose and sucrose) by alkaline permanganate anion and of sugar and sugar alcohols ${ }^{123}$ (sucrose, maltose, sorbitol, glucose, mannitol, fructose) by $\mathrm{KMnO}_{4}$ in alkaline buffer $\mathrm{NaHCO}_{3} / \mathrm{NaOH}$ reveals that each reaction is first order with respect to [substrate] and [oxidant]. The reaction rate increased by increase in $\mathrm{pH}$, ionic strength and temperature as well as the reactant concentrations with the exception of sorbitol where reaction rate decreased with increase in sugar concentration. The mechanism proceed through the formation of enediol intermediate complex.

The kinetic studies on the oxidation of some aldoses, amino sugars and methylated sugars by tris[pyridine-2carboxylato] manganese(III) in sodium picolinate-picolinic acid showed that the reactions are first order to both $\mathrm{Mn}(\mathrm{III})$ and sugar concentration but are independent to sodium picolinate-picolinic acid buffer medium. The reaction proceed through the intermediate formation of a free radical between the reactants in the rate determining step. The free radical is then rapidly oxidized by another [Mn(III)] to give products ${ }^{124}$ (Scheme-XXIII).

In the kinetic study of D-glucose oxidation by bromine in aqueous solution, the $\mathrm{pH}$ has a strong influence on reaction rate $^{125}$

Kinetics of oxidation of glucose with hypobromous acid in a nearly neutral medium using spectrometry technique have been reported ${ }^{126}$. The reaction was first order with respect to [glucose] and [hypobromous acid] and had negligible salt effect.

Chromium(VI) oxidation of reducing sugars: Oxides and oxyacids of $\mathrm{Cr}(\mathrm{VI})$ are powerful oxidants. Chromic esters have been proposed as an intermediates in $\mathrm{Cr}(\mathrm{VI})$ oxidations. Decomposition of the chromic ester involves removal of the proton attached to the oxygen bearing carbon. Atleast two mechanisms have been suggested for this step $^{127}$. Also an alternative proposal has been suggested that involves the formation of a coordination complex that decomposes to radical species, which are further oxidized to products ${ }^{128}$.
Oxidations with $\mathrm{Cr}(\mathrm{VI})$ is a complex reaction that is influenced by the solvent, acidity of the reaction medium, the structure of the substrate, the temperature and other factors hence difficult to study from mechanistic point of view. Chromic acid (chromium trioxide) is a more useful oxidant than either nitric acid or permanganate, because it is stable in organic solvents. Various $\mathrm{Cr}(\mathrm{VI})$ oxidants have been employed in synthesis ${ }^{129}$. Reagents prepared from chromic acid are useful oxidant for the oxidation of isolated alcoholic group in partially protected sugar derivatives ${ }^{130}$.

The oxidizability of acetals with chromium trioxideacetic acid was investigated by Angyal et al. ${ }^{131,132}$. The acetylated methyl glycosides react with chromium trioxide-acetic acid to give acetylated methyl aldonates having a keto group in place of oxygen atom formerly involved in the furanoid or pyranoid ring; methyl $\beta$-D-glucopyranoside tetra acetate thus afforded 2,3,4,6-tetra-O-acetyl-D-xylo-5-hexulosonate.

The chromic acid-pyridine complex oxidizes the free hydroxyl group of carbohydrates to glyculoses ${ }^{133}$. The oxidation of sugar derivatives with pyridinium chlorochromate (PCC) and pyridinium dichromate (PDC) have been reported ${ }^{134}$.

The kinetic studies on the oxidation of aldosugar in perchloric acid medium revealed that the reaction may proceed either through the decomposition of chromic acid ester or by a direct attack on the secondary hydrogen atom ${ }^{49-52}$. It was assumed that protonated $\beta$-pyranoid form of D-glucose and D-ribose was attacked directly by protonated form of chromic acid.

The oxidation mechanism of aldoses and sugar phosphates by $\mathrm{Cr}(\mathrm{VI})$ have been reviewed ${ }^{135}$. Sala et al. studied the kinetics of oxidation of aldoses ${ }^{136,137}$ and deoxyaldoses ${ }^{136-140}$ disaccharides $^{141}$ and lactone/sugar acid ${ }^{142}$ in perchloric acid solution using an excess of sugar over $\mathrm{Cr}(\mathrm{VI})$. For the 2-deoxysugars, the lack of the 2-OH group accelerate the total reaction and 6-OH group may bind $\mathrm{Cr}(\mathrm{VI})$ as an intermediate ester. The reaction occurs through both $\mathrm{Cr}(\mathrm{VI}) \rightarrow \mathrm{Cr}(\mathrm{III})$ and $\mathrm{Cr}(\mathrm{VI}) \rightarrow$ $\mathrm{Cr}(\mathrm{V}) \rightarrow \mathrm{Cr}(\mathrm{III})$ paths. Intermediate sugar alkoxide radicals may be trapped with 5,5-dimethyl-1-pyrroline and $\mathrm{N}$-oxide (DMPO) and observed by electron paramagnetic resonance. These sugar radicals react with $\mathrm{Cr}(\mathrm{VI})$ to form $\mathrm{Cr}(\mathrm{V})$ in a rapid step. The EPR spectra showed that five- and six-coordinate oxochromate $(\mathrm{V})$ intermediates are formed, with the aldose or the aldonic acid ${ }^{138}$, disaccharides ${ }^{141}$ acting as bidentate ligands. Mechanistic studies on the oxidation of D-galactose-1,4lactone by $\mathrm{Cr}(\mathrm{VI})$ leads to D-lyxonic acid, $\mathrm{CO}_{2}$ and $\mathrm{Cr}(\mathrm{III})$ as final products when an excess of sugar acid over $\mathrm{Cr}(\mathrm{VI})$ is used $^{143}$. The reaction occurs through $\mathrm{Cr}(\mathrm{VI}) \rightarrow \mathrm{Cr}(\mathrm{III})$ and $\mathrm{Cr}(\mathrm{VI}) \rightarrow \mathrm{Cr}(\mathrm{V}) \rightarrow \mathrm{Cr}$ (III) paths. The complete rate law for the $\mathrm{Cr}(\mathrm{VI})$ oxidation is $-\mathrm{d}[\mathrm{Cr}(\mathrm{VI})] / \mathrm{dt}=\left(\mathrm{k}_{0}+\mathrm{k}_{\mathrm{H}}\left[\mathrm{H}^{+}\right]\right)$[gal] $[\mathrm{Cr}(\mathrm{VI})] . \mathrm{Cr}(\mathrm{V})$ is formed in a rapid step by the reaction of the $\mathrm{CO}^{2-}$ radical with $\mathrm{Cr}(\mathrm{VI}) . \mathrm{Cr}(\mathrm{V})$ reacts with the substrate faster than does $\mathrm{Cr}(\mathrm{VI})$. The $\mathrm{Cr}(\mathrm{V})$ oxidation follows the rate law $-\mathrm{d}[\mathrm{Cr}(\mathrm{V})] / \mathrm{dt}=\left(\mathrm{k}_{\mathrm{o}}^{\prime}+\mathrm{k}_{\mathrm{H}}^{\prime}\left[\mathrm{H}^{+}\right]\right.$[gal]. The EPR spectra showed that several intermediate $\left[\mathrm{Cr}(\mathrm{O})(\text { gala })_{2}\right]^{-}$linkage isomers are formed in rapid pre-equilibria before the redox steps ${ }^{143}$.

The kinetics of oxidation of 2-acetamido-2-deoxy-Dglucose (GlcNAc) ${ }^{144}$ by $\mathrm{Cr}(\mathrm{VI})$ led to the rate law: $-\mathrm{d}[\mathrm{Cr}(\mathrm{VI})] /$ $\mathrm{dt}=\left(\mathrm{a}+\mathrm{b}\left[\mathrm{H}^{+}\right]^{2}+\mathrm{c}[\mathrm{GlcNAc}]_{2}\left[\mathrm{H}^{+}\right]^{2}\right)[\mathrm{Cr}(\mathrm{VI})]_{\mathrm{T}}$. This rate law corresponds to the reaction leading to the formation of 


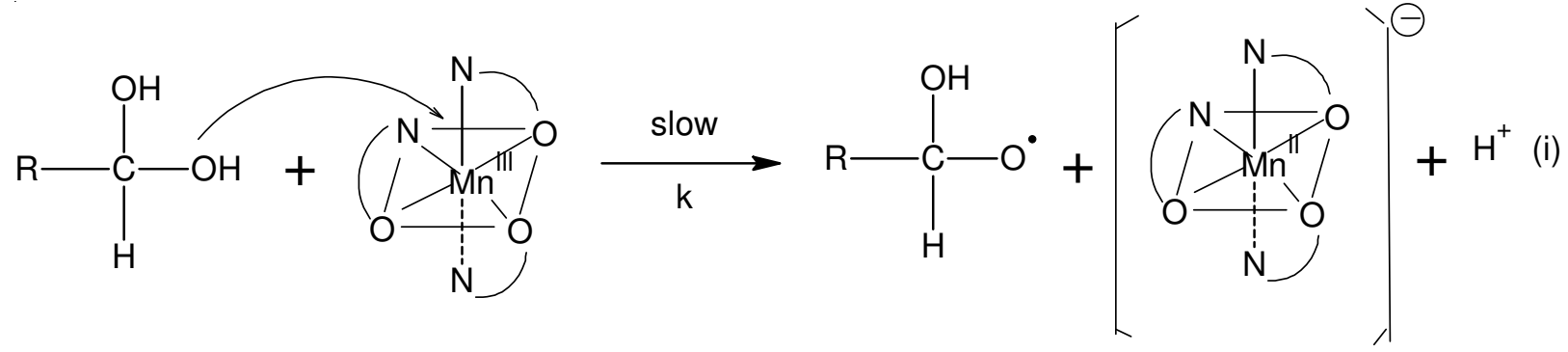<smiles>O=C([O-])c1ccccn1</smiles>

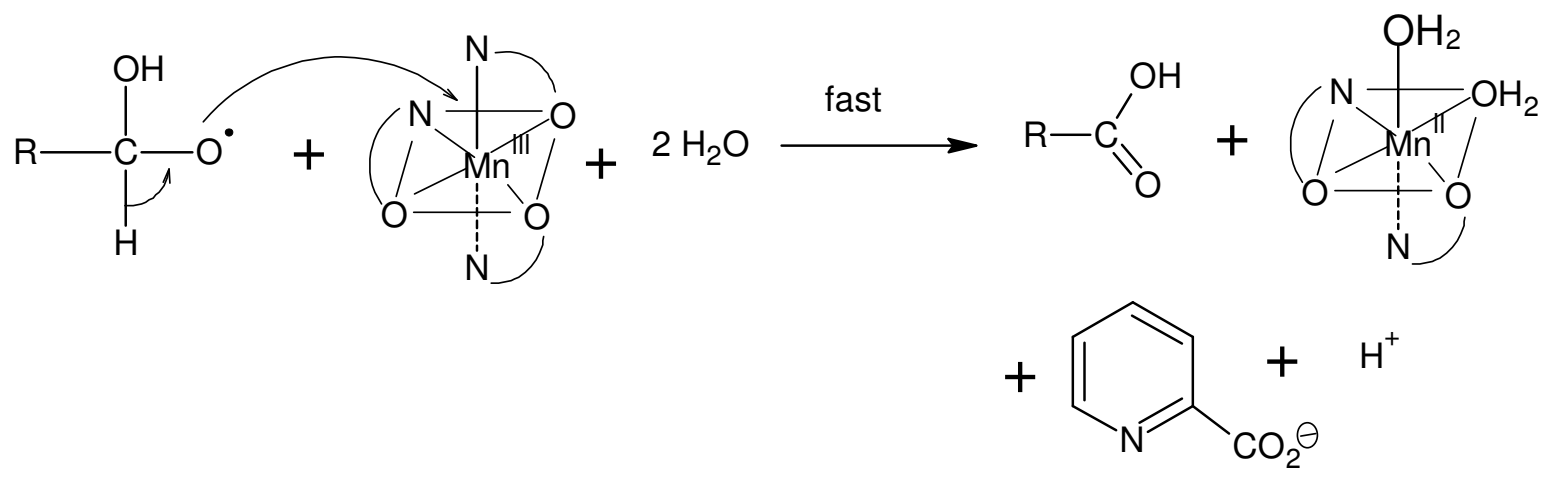

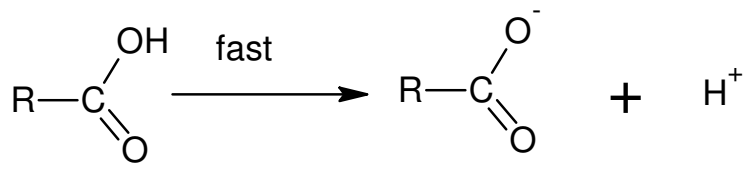

$$
\begin{aligned}
& \mathrm{R}=-(\mathrm{CHOH})_{2} \mathrm{CH}_{2} \mathrm{OH} \text { for erythrose } \\
& \mathrm{R}=-\mathrm{CHOHCH}_{2} \mathrm{OH} \text { for glyceralehyde }
\end{aligned}
$$

\section{Scheme-XXIII}

2-acetamido-2-deoxy-D-gluconic acid when an excess of aldose over chromium is employed. The study revelead that acetate does not acts as a blocking group compelling chromium to interact with anomeric hydroxyl group only as was obtained with 2-deoxyglucose ${ }^{140}$ but it behave as a binding site.

The kinetic results for the oxidation of L-rhamnose and D-mannose by $\mathrm{Cr}(\mathrm{VI})$ in aqueous acetic acid have been reported $^{145}$ and compared with those obtained in water ${ }^{136}$.

The oxidation of $\alpha$ - and $\beta$-D-glucose by $\operatorname{Cr}(\mathrm{VI})$ was carried out in dimethyl sulfoxide in the presence of pyridinium $p$-toluenesulfonate, a medium in which mutarotation is slower than the redox reaction. Both anomers reduce $\mathrm{Cr}(\mathrm{VI})$ by formation of an intermediate ester which is the precursor of slow redox step. The equilibrium constant for the complex formation and the rate of electron transfer within the complex, have been determined for each anomer ${ }^{146}$. The EPR spectra showed that $\alpha$-anomer forms several linkage isomers of the five-coordinate $\mathrm{Cr}(\mathrm{V})$ bis-chelate, while $\beta$-D-glucose affords a mixture of six-coordinate $\mathrm{Cr}(\mathrm{V})$ mono-chelate and five-coordinate $\mathrm{Cr}(\mathrm{V})$ bis-chelate.

The kinetics of oxidation of D-ribose ${ }^{147}$ by $\mathrm{Cr}(\mathrm{VI})$ in perchloric acid is first order in both [oxidant] and [reductant], whereas the apparent order of $\mathrm{H}^{+}$is a little lower than 2. At 
low $[\mathrm{Cr}(\mathrm{VI})]_{\mathrm{o}}$ the reaction is catalyzed by $\mathrm{Mn}(\mathrm{II})$. The catalytic reaction pathway is zero order in $\mathrm{Cr}(\mathrm{VI})$ and first order both in $[\mathrm{D}$-ribose $]$ and $\left[\mathrm{H}^{+}\right]$. At high $[\mathrm{Cr}(\mathrm{VI})]_{0}$ the reaction is inhibited by $\mathrm{Mn}(\mathrm{II})$ because it trapes intermediate $\mathrm{Cr}(\mathrm{VI})$. In the the presence of $\mathrm{Mn}$ (II) the formation of $\mathrm{Mn}(\mathrm{III})$ as an intermediate has been detected.

The oxidation of D-glucose with $\mathrm{Cr}(\mathrm{VI})$ in aqueous perchloric acid proceeds via 1:1 complex which is considered to be chromium bonded to anomeric - $\mathrm{OH}$ group. The reaction products are D-1, 4 glucolactone and $\mathrm{Cr}(\mathrm{III})$. The kinetics of electron transfer reaction to $\mathrm{Cr}$ (III) have been investigated ${ }^{148}$. $\mathrm{Cr}(\mathrm{VI})$ oxidized $\alpha$-D-glucopyranoside and methyl $\alpha$-Dmannopyranoside to $\mathrm{Cr}$ (III) and methyl-D-glycofuranurono6,3-lactone as final products when an excess of the methyl glycoside over $\mathrm{Cr}(\mathrm{VI})$ was used $^{149}$. The reaction occurs $\mathrm{Cr}(\mathrm{VI})$ $\rightarrow \mathrm{Cr}(\mathrm{V}) \rightarrow \mathrm{Cr}(\mathrm{III})$ and $\mathrm{Cr}(\mathrm{VI}) \rightarrow \mathrm{Cr}(\mathrm{V}) \rightarrow \mathrm{Cr}(\mathrm{III})$ paths, the $\mathrm{Cr}(\mathrm{VI}) / \mathrm{Cr}(\mathrm{V})$ reduction being the slow step. In acid medium, intermediate $\mathrm{Cr}(\mathrm{V})$ reacts with the substrate faster than $\mathrm{Cr}(\mathrm{VI})$ does. $\mathrm{Cr}(\mathrm{VI})$ mono-bis-chelates were detected by EPR spectroscopy and EPR spectra showed that the distribution of these species essentially depends on the solution acidity.

The oxidation of D-lactobionic acid by $\mathrm{Cr}(\mathrm{VI})$ to the 2-ketoaldobionic acid and $\mathrm{Cr}$ (III) as final products has been explained by a mechanism which involves the formation of intermediate $\mathrm{Cr}(\mathrm{IV})$ and $\mathrm{Cr}(\mathrm{V})$ species ${ }^{150}$. The EPR spectra show that five-coordinate oxo $\mathrm{Cr}(\mathrm{V})$ bischelates are formed at pH 1-5 with aldobionic acid bound to $\mathrm{Cr}(\mathrm{V})$ through the $\alpha$-hydroxy acid group. Redox and complexation chemistry of the $\mathrm{Cr}(\mathrm{VI}) / \mathrm{Cr}(\mathrm{V})-\mathrm{D}$-galacturonic acid system have also been reported $^{151}$.

Intermediacy of free radicals and $\mathrm{Cr}$ (II) in the reaction of $\mathrm{HCrO}_{4}^{-}$with a variety of neutral and acid saccharides, hydroxy acids and aliphatic alcohols was demonstrated by the observation of free radical induced polymerization of acrylonitrile and acrylamide and detection of $\mathrm{CrO}_{2}{ }^{2+}$ when working in $\mathrm{O}_{2}{ }^{-}$ saturated solutions and low $\left[\mathrm{HCrO}_{4}^{-}\right]^{152}$. The results are interpreted in terms of a mechanism combining the $\mathrm{Cr}(\mathrm{VI}) \rightarrow \mathrm{Cr}(\mathrm{V})$ $\rightarrow \mathrm{Cr}(\mathrm{II})$ and $\mathrm{Cr}(\mathrm{VI}) \rightarrow \mathrm{Cr}(\mathrm{IV}) \rightarrow \mathrm{Cr}(\mathrm{III})$ pathways.

Oxidation kinetics of D-fructose by $\mathrm{Cr}(\mathrm{VI})$ have been studied at various concentrations of reactants and acidities ${ }^{153}$. The reaction takes place through a complex multistep mechanism which involves the formation of intermediate $\mathrm{Cr}(\mathrm{IV})$ and $\mathrm{Cr}(\mathrm{V}) . \mathrm{Cr}(\mathrm{IV})$ reacts with D-fructose much faster than $\mathrm{Cr}(\mathrm{V})$ and $\mathrm{Cr}(\mathrm{VI})$. The rate law is $-\mathrm{d}[\mathrm{Cr}(\mathrm{VI})] / \mathrm{dt}=(\mathrm{a}+\mathrm{b}[\mathrm{D}-\mathrm{Fru}]$ $\left[\mathrm{H}^{+}\right]^{2}[\mathrm{Cr}(\mathrm{VI})]_{\mathrm{T}}$. The EPR spectra show that five-coordinate oxo- $\mathrm{Cr}(\mathrm{V})$ bischelates are formed in a rapid pre-equilibria before the redox step $\mathrm{Cr}(\mathrm{V})$ to $\mathrm{Cr}(\mathrm{III})$.

The oxidation of 3-O-methyl-D-glucopyranose(Glc3Me) by $\mathrm{Cr}(\mathrm{VI})$ in acid medium to $\mathrm{Cr}(\mathrm{III})$, formic acid and 2-Omethyl-D-arabinose as final products when an excess of sugar over $\mathrm{Cr}(\mathrm{VI})$ is used takes place through the combination of $\mathrm{Cr}(\mathrm{VI}) \rightarrow \mathrm{Cr}(\mathrm{IV}) \rightarrow \mathrm{Cr}(\mathrm{II})$ and $\mathrm{Cr}(\mathrm{VI}) \rightarrow \mathrm{Cr}(\mathrm{IV}) \rightarrow \mathrm{Cr}(\mathrm{III})$ pathways ${ }^{154}$. Intermediacy of free radicals and $\mathrm{Cr}(\mathrm{II})$ in the reaction was demonstrated by the observation of induced polymerization of acrylamide and detection of $\mathrm{CrO}_{2}{ }^{2+}$ formed by the reaction of $\mathrm{Cr}(\mathrm{II})$ with $\mathrm{O}_{2}$. Intermediate oxo-Cr(V)Glc3Me were detected by EPR spectroscopy. The $\mathrm{C}_{1}-\mathrm{C}_{2}$ bond cleavage of Glc3Me upon reaction with $\mathrm{Cr}(\mathrm{VI})$ distinguishes this derivative from glucose, which is oxidized to gluconic acid.
Kinetic studies results of the interaction of hypervalent chromium with 2-amino-2-deoxy-D-glucopyranose in acid media afforded a mechanism combining one- and twoelectron pathways; $\mathrm{Cr}(\mathrm{VI}) \rightarrow \mathrm{Cr}(\mathrm{IV}) \rightarrow \mathrm{Cr}(\mathrm{II})$ and $\mathrm{Cr}(\mathrm{VI}) \rightarrow$ $\mathrm{Cr}(\mathrm{IV}) \rightarrow \mathrm{Cr}(\mathrm{III})$. Oxo-Cr(V) bis- and mono-chelates were detected by EPR spectroscopy at low $\left[\mathrm{H}^{+}\right]^{155}$.

Kinetics of oxidation of D-galactose, D-xylose and Darabinose by peroxydichromate in very dilute sulphuric acid is of first order each in [substrate], [oxidant] and $\left[\mathrm{H}_{2} \mathrm{SO}_{4}\right]$. $\mathrm{HCrO}_{4}^{-}$appears to be predominant oxidant ${ }^{156}$.

The kinetics and mechanism of the oxidation of Dgalactose by chromium(VI) in the absence and presence of cerium(IV) and manganese(II) have been studied in aqueous perchloric acid media. The reaction is first order in both [D-galactose] and $\left[\mathrm{H}^{+}\right]$. The cerium(IV) inhibits the oxidation path whereas $\mathrm{Mn}(\mathrm{II})$ catalyses the reactions. The observed inhibitory role of $\mathrm{Ce}$ (IV) suggests the formation of $\mathrm{Cr}$ (IV) as an intermediate. In the Mn(II) catalyzed path, the D-galactosemanganese(II) complex is considered to be an active oxidant. In this path, the complex forms a ternary chromate ester with $\mathrm{Cr}(\mathrm{IV})$ which subsequently undergoes acid catalyzed redox decomposition in the rate determining step ${ }^{157}$.

The kinetics of oxidation of D-glucose and some other monosaccharides by pyridinium fluorochromates (PFC) $)^{158}$ and pyridinium chlorochromate $(\mathrm{PCC})^{159}$ in aqueous perchloric acid have been reported. The reactions are first order each in [oxidant], [sugar] and $\left[\mathrm{H}^{+}\right]$. In the oxidation by PFC, a mechanism involving hydride-ion transfer has been proposed. On the other hand, oxidation by PCC follows two pathways, i.e. one involving a $\mathrm{C}-\mathrm{H}$ bond cleavage, the other a $\mathrm{C}-\mathrm{C}$ bond cleavage. The $\mathrm{C}-\mathrm{H}$ bond cleavage takes place by a hydrideion transfer and C-C bond fission to proceed via a cyclic chromate ester.

Pyridinium chlorochromate (PCC) oxidation of Dglucose $^{160}$, D-mannose ${ }^{161}$ and some other monosaccharides ${ }^{162}$ in prechloric acid medium at constant ionic strength proceeds by specific cleavage of $\mathrm{C}_{1}-\mathrm{C}_{2}$ bond of the substrate resulting in the formation of arabinose. the reaction follows via a direct hydride-ion transfer of the axial anomeric proton of $\beta$ pyranose.

The kinetics of oxidation of D-glucose $\mathrm{e}^{163}$ and some other monosaccharides ${ }^{164-167}$ with quinolinium chlorochromate (QCC) have been studied in aqueous acetic acid medium [50\% $(\mathrm{v} / \mathrm{v})]$ in the presence of perchloric acid at constant ionic strength. The reactions are first order each in [oxidant], [substrate] and $\left[\mathrm{H}^{+}\right]$. The oxidation proceed via direct hydride-ion transfer mechanism involving specific cleavage of $\mathrm{C}_{1}-\mathrm{C}_{2}$ bond of the substrate to give the products.

The kinetics and mechanism of oxidation of some monosaccharidess ${ }^{168}$ like aldohexoses ${ }^{169}$ by quinolinium fluorochromate in aqueous acetic acid $50 \%$ (v/v) medium has been investigated. The reaction has been found to be first order with respect to each of the substrate and oxidant. The reaction is catalyzed by acid and follows a first order dependence on $\left[\mathrm{H}^{+}\right]$. The rate of reaction is increased by decrease in dielectric constant of medium. Ionic strength has no effect on reaction rate. A 1:1 stoichiometry of the reaction has been reported. 
Oxidation kinetics of some reducing sugars ${ }^{170-174}$ with tetraethylammonium chlorochromate (TEACC) in aqueous acetic acid in presence of $\mathrm{HClO}_{4}$ was first ordered in [TEACC], [sugar] and $\left[\mathrm{H}^{+}\right]$.

\section{REFERENCES}

1. B. Capon, Chem. Rev., 69, 407 (1969).

2. O. Varela, Adv. Carbohydr. Chem. Biochem., 58, 307 (2003).

3. J.W. Green, W. Pigman and D. Horton, The Carbohydrates; Chemists and Biochemists, Academic Press, New York, edn. 2, Vol. 1B, p. 1101 (1980).

4. R.P. Bhatnagar and A.G. Fadnis, J. Sci. Ind. Res., 45, 90 (1986).

5. K.S. Rangappa, J. Indian Chem. Soc., 81, 1025 (2004).

6. E.O. Odebunmi and A.S. Ogunlaja, Curr. Res. Chem., 3, 16 (2011).

7. D. Steinborn and H. Junicke, Chem. Rev., 100, 4283 (2000).

8. S.P. Mushran and M.C. Agarwal, J. Chem. Soc. Perkin Trans. II, 762 (1973).

9. R. Sanehi, K.C. Gupta, R.M. Mehrotra and S.P. Mushran, Bull. Chem. Soc. (Japan), 48, 330 (1975).

10. S.P. Mandawat, V. Singh and D.R. Singh, J. Indian Chem. Soc., 57, 318 (1980).

11. S.P. Mandawat, V. Singh and D.R. Singh, Polish J. Chem., 55, 889 (1981).

12. R.N. Singh and O. Prakash, Indian J. Chem., 21A, 616 (1982).

13. V. Shashikala and K.S. Rangappa, Indian J. Chem., 41B, 1907 (2002).

14. V. Shashikala and K.S. Rangappa, Oxid. Commun., 27, 316 (2004).

15. K.M. Usha and T. Gowda, J. Chem. Sci., 118, 351 (2006).

16. B.T. Gowada, N. Damodara and Jyothi, Int. J. Chem. Kinet., 37, 572 (2005).

17. M.K. Singh, N. Prassad and H.K. Sinha, Asian J. Chem., 6, 636 (1994).

18. M.K. Singh, N. Prassad and H.K. Sinha and V. Singh, J. Indian Chem. Soc., 70, 74 (1993).

19. S.S. Nizami, R. Azmat and F. Uddin, J. Saudi Chem. Soc., 9, 189 (2005).

20. B.P. Singh, V.P. Singh and E.B. Singh, J. Indian Chem. Soc., 66, 876 (1989).

21. T. Mahmood, Q. Haque, I. Mahmood, S.A. Ali and Z.T. Maqsood, Transaction C: Chem. Chem. Eng., 16, 22 (2009).

22. R.S. Singh, Acta Cien. Ind. Chem., 23, 139 (1997).

23. R.S. Singh, Acta Cien. Ind. Chem., 19, 54 (1993).

24. F.O. Okeola, E.O. Odebunmi and O.A. Olagoke, Adv. Environ. Biol., 4, 451 (2010).

25. S.M. Mayanna and C.C. Gowda, Oxid. Commun., 23, 34 (2000).

26. B.S. Moodithaya and B.T. Gowda, Z. Phys. Chem. (Munich), 192, 207 (1995).

27. N. Gupta, S. Rahmani and A.K. Singh, Oxid. Commun., 22, 237 (1999).

28. A.K. Singh, N. Chaurasia, S. Rahmani, J. Srivastava and B. Singh, Catal. Lett., 95, 135 (2004).

29. R. Tripathi, N. Kambo and S.K. Upadhyay, Bulg. Chem. Ind., 75, 18 (2004).

30. Ashish, S.P. Singh and A.K. Singh, Oxid. Commun., 28, 630 (2005).

31. A.K. Singh, S. Srivastava, J. Srivastava and P. Singh, J. Molecul. Catal. A: Chem., 278, 72 (2007).

32. S.P. Singh, A.K. Singh and A.K. Singh, J. Mol. Catal. A, 293, 97 (2008).

33. S.P. Singh, A.K. Singh and A.K. Singh, J. Carbohydr. Chem., 28, 278 (2009).

34. A.K. Singh, S. Srivastava, J. Srivastava and R. Singh, Carbohydr. Res., 342, 1078 (2007).

35. H.S. Singh, A. Gupta, A.K. Singh and B. Singh, Transition Met. Chem., 23, 277 (1998)

36. N. Kambo and S.K. Upadhyay, Indian J. Chem., 43A, 1210 (2004).

37. N. Kambo, S.K. Upadhyay and A.K. Jain, Oxid. Commun., 26, 502 (2003).

38. R. Tripathi and S.K. Upadhyay, Int. J. Chem. Kinet., 36, 441 (2004).

39. K.K.S. Gupta and B.A. Begum, Int. J. Chem. Kinet., 31, 477 (1999).

40. K.K.S. Gupta, B.A. Begum and B. Pal, Carbohydr. Res., 309, 303 (1998).

41. P. Bajpai, A. Shukla and S.K. Upadhyay, Int. J. Chem. Kinet., 28, 413 (1999).

42. A. Goel, Shailja and Ruchi, J. Indian Chem. Soc., 85, 286 (2004).

43. S.O. Olusanya and E.O. Odubunmi, The Pacific J. Sci. Technol., 12, 333 (2011).
44. K.V. Krishna and P.J.P. Rao, Transition Met. Chem., 20, 344 (1995).

45. K.V. Rao, M.T. Rao and M. Adhinaryana, Int. J. Chem. Kinet., 27, 55 (2004).

46. P. Olavi, I. Virtanen and S. Kurkusio, Carbohydr. Res., 138, 215 (1985).

47. P. Olavi, I. Virtanen and R. Lindroos-Heinanen, Acta Chem. Scand., B42, 411 (1988).

48. K.K.S. Gupta and S.N. Basu, Carbohydr. Res., 72, 139 (1979).

49. K.K.S. Gupta and S.N. Basu, Carbohydr. Res., 80, 223 (1980)

50. K.K.S. Gupta and S.N. Basu, Carbohydr. Res., 86, 7 (1980).

51. K.K.S. Gupta and S.N. Basu and S.S. Gupta, Carbohydr. Res., 97, 1 (1981).

52. K.K.S. Gupta, S.S. Gupta and S.N. Basu, Carbohydr. Res., 71, 75 (1979).

53. A. Kumar, K.C. Koshal and Vishnu, Trends Carbohydr. Chem., 5, 163 (1999).

54. Z. Khan, P.S.S. Babu and Kabir-ud-Din, Carbohydr. Res., 339, 133 (2004).

55. A. Kumar, M. Gogia, K.C. Koshal and Vishnu, Trends Carbohydr. Chem., 6, 163 (2000).

56. E.O. Odebumni, A.S. Ogunlaja and S.O. Owalude, J. Chil. Chem. Soc., 55, 293 (2010).

57. H.K. Okoro and E.O. Odebunmi, Scient. Res. Essays, 5, 2588 (2010).

58. L.F. Sala, L. Ciullo, R. Lafarga and S. Signorella, Polyhedron, 14, 1207 (1995).

59. S. Signorella, R. Lafarga, L. Ciullo and L.F. Sala, Carbohydr. Res., 259, 35 (1994).

60. M.A. Nikath, N. Anitha, K.M.L. Rai and K.S. Rangappa, Trends Carbohydr. Chem., 4, 109 (1999).

61. N. Anitha, K.S. Rangappa and K.M.L. Rai, Indian J. Chem., 38B, 1046 (1999).

62. K.S. Rangappa, N. Anitha, M.A. Nikath and A.T. Gowda, Asian J. Chem., 11, 401 (1999).

63. K.K.S. Gupta, S.N. Basu and A. Mahapatra, J. Carbohydr. Chem., 8, 713 (1989).

64. P.O.I. Virtanen, R. Lindroos, E. Oikarinen and J. Vaskuri, Carbohydr. Res., 167, 29 (1987).

65. A. Agarwal, G. Sharma, C.L. Khandelwal and P.D. Sharma, J. Chem. Res., 3, 233 (2002).

66. M.P. Sah, J. Indian Chem. Soc., 71, 613 (1994).

67. M.P. Sah, J. Indian Chem. Soc., 72, 173 (1995).

68. M.P. Sah, J. Indian Coun. Chem., 11, 25(1995).

69. M.P. Sah, Asian J. Chem., 12, 9 (2000).

70. M.P. Sah, J. Indian Coun. Chem., 15, 57 (1998).

71. B.S. Moodithaya and B.T. Gowda, Oxid. Commun., 23, 408 (2000).

72. K.K.S. Gupta, S.S. Gupta, A. Tarafder, U. Chatterjee, T. Samanta and U. Sharma, Carbohydr. Res., 117, 81 (1983).

73. K.K.S. Gupta, U. Chatterjee and A. Mahapatra, J. Chem. Res. (S), 260 (1988).

74. K.K.S. Gupta, A. Tarafder and A. Mahapatra, J. Chem. Res. (S), 306 (1987).

75. K.K.S. Gupta, N. Debnath, N. Bhattacharjee, A. Banerjee and S.N. Basu, J. Indian Chem. Soc., 77, 152 (2000).

76. S. Srivastava, A. Kumar and P. Srivastava, Oxid. Commun., 29, 660 (2006).

77. S. Srivastava, A. Kumar and P. Srivastava, Indian J. Agric. Chem., 40, 107 (2007)

78. S. Srivastava, A. Kumar, P. Srivastava and S. Singh, Oxid. Commun., 32, 546 (2009).

79. S. Srivastava and P. Srivastava, Der Chem. Sin., 1, 13 (2010).

80. V.K. Shukla, M. Kumar and R.A. Singh, Oxid. Commun., 30, 368 (2007).

81. A.K. Singh, D. Chopra, S. Rahmani and B. Singh, Carbohydr. Res., 314, 157 (1998).

82. A.K. Singh, T. Gupta, V.K. Singh, S. Rahmani, D. Kesharwani and B. Singh, Oxid. Commun., 23, 609 (2000).

83. A.K. Singh, T. Gupta, V.K. Singh, D. Kesharwani and B. Singh, Indian J. Chem., 23, 416 (2000)

84. A.K. Singh, R. Srivastava, S. Srivastava, J. Srivastava, S. Rahmani and B. Singh, J. Mol. Catal. A, 310, 64 (2009).

85. A.K. Singh, S. Rahmani, V.K. Singh, V. Gupta, D. Kesharwani and B. Singh, Indian J. Chem., 40A, 519 (2001).

86. A.K. Singh, S. Rahmani, V. Singh, V. Gupta and B. Singh, Oxid. Commun., 23, 55 (2000).

87. S.K. Rajput, A. Sharma and P. Chandrakar, J. Indian Chem. Soc., 84, 777 (2007).

88. N. Gupta, N. Chaurasia, V. Singh and A.K. Singh, Oxid. Commun., 23, 42 (2000).

89. A.K. Singh, R. Singh, J. Srivastava, S. Rahmani and S. Srivastava, J. Organomet. Chem., 692, 4270 (2007) 
90. A.K. Singh, R.K. Singh, R. Srivastava, S. Srivastava, J. Srivastava and S. Rahmani, Transition Met. Chem., 35, 349 (2010).

91. A.K. Singh, V. Singh, A. Kumar, N. Gupta and B. Singh, Carbohydr. Res., 337, 345 (2002).

92. A.K. Singh, J. Srivastava and S. Rahmani, J. Mol. Catal. A, 278, 72 (2007).

93. A.K. Singh, J. Srivastava, Shalini and S. Rahmani, Chin. J. Chem., 26, 1057 (2008)

94. A.K. Singh, S. Rahmani, B. Singh, R. Kumar and M. Singh, J. Phys. Org. Chem., 17, 249 (2004).

95. A.K. Singh, V. Singh, A. Srivastava and J. Srivastava, Indian J. Chem., 45A, 599 (2006).

96. A.K. Singh, J. Srivastava, S. Rahmani and V. Singh, Carbohydr. Res., 341, 397 (2006).

97. A.K. Singh, V. Singh, S. Rahmani, A.K. Singh and B. Singh, J. Molecul. Catal. A, 197, 91 (2003).

98. A.K. Singh, S. Yadav, R. Srivastava, J. Srivastava and S. Rahmani, J. Organomet. Chem., 695, 2213 (2010).

99. M. Kiviniemi, P. Tomperi and P.O.I. Virtanen, J. Carbohydr. Chem., 13, 457 (1994).

100. S. Srivastava and P. Singh, Bull. Catal. Soc. India, 7, 12 (2008).

101. S. Srivastava, S. Singh, S. Srivastava and P. Srivastava, J. Indian Chem. Soc., 85, 647 (2008).

102. S. Srivastava and S. Singh, Asian J. Chem., 20, 973 (2008).

103. K.K.S. Gupta, A. Sanyal, P.S. Tribedi and S.S. Gupta, J. Chem. Res. (S), 484 (1993).

104. K.N. Reddy, K.R. Reddy, K.C. Rajanna and P.K. Saiprakash, Oxid. Commun., 19, 381 (1996).

105. N. Madhavi, B.S. Sundar and P.S. Radhakrishnamurti, Russ. J. Phys. Chem., 79, 1579 (2005).

106. V.N. Kislenoko, A.A. Berlin and N.V. Litovchnko, Zh. Obshch. Khim., 66, 854 (1996).

107. V.N. Kislenoko, A.A. Berlin and N.V. Litovchnko, Kinet. Catal., 38, 359 (1997)

108. M.J.A. Abualreish, Int. J. Chem., 17, 7 (2007).

109. S. Srivastava and K.C. Nand, J. Indian Coun. Chem., 31, 47 (1997).

110. I. Kistayya, M.S. Reddy and S. Kandlikar, Indian J. Chem., 25A, 905 (1986).

111. A.K. Singh, A. Singh, M. Saxena, R. Gupta and B. Singh, Oxid. Commun., 15, 56 (1992).

112. T. Kistayya, M.A.A. Siddiqui and S. Kandlikar, Oxid. Commun., 10, 11 (1987).

113. G.A. Neyhart, C. Cheng and H.H. Thorp, J. Am. Chem. Soc., 117, 1463 (1995).

114. A.G. Fadnis and S. Arzare, Oxid. Commun., 23, 50 (2000).

115. A.G. Fadnis and S. Rawat, J. Indian Chem. Soc., 80, 759 (2003).

116. S. Signorell, L. Ciullo, R. Lafarga and L.F. Sala, New J. Chem., 20, 989 (1996).

117. K.K.S. Gupta, A. Mahapatra and B. Ghosh, Carbohydr. Lett., 1, 231 (1995).

118. K.K.S. Gupta, B. Pal and B.A. Begum, Carbohydr. Res., 330, 115 (2001).

119. D.F. Latona, J. Chem. Soc. (Nigeria), 29, 5 (2004).

120. E.O. Odebunmi, S.A. Iwarere and S.O. Owalude, Int. J. Chem. 16, 167 (2006)

121. E.O. Odebunmi, A.O. Oyetunji and H. Marufu, Nigerian J. Sci., 33, 145 (1999).

122. E.O. Odebunmi and S.O. Owalude, J. Iran. Chem. Soc., 5, 623 (2008).

123. H.K. Okoro and E.O. Odebunmi, Int. J. Phys. Sci., 4, 471 (2009).

124. K.K.S. Gupta and B.A. Begum, Carbohydr. Res., 315, 70 (1999).

125. B.N. Grgur, D.L. •ugic, M.M. Gvozdenovic and T. Lj. Trišovic, Carbohydr. Res., 341, 1779 (2006).

126. H. Yang, B. Shen, T. Peng, G. Wang, Y. Tang and P. Zhang, Hangzhou Daxue Хuebao, Ziran Kexueban, 23, 168 (1996).

127. M.B. Smith, Organic Synthesis, McGraw-Hill, NewYork, p. 223 (1994).

128. M. Rhaman and J. Rocek, J. Am. Chem. Soc., 93, 5455 (1971); 93, $5462(1971)$

129. M.B. Smith, Organic Synthesis, McGraw-Hill, NewYork, pp. 221-234 (1994.)

130. J.W. Green, W. Pigman and D. Horton, The Carbohydrates; Chemists and Biochemists, Academic Press, New York, edn. 2, Vol. 1B, p. 1139 (1980).
131. S.J. Angyal and K. James, Aust. J. Chem., 23, 1209 (1970); 24, 1219 (1971).

132. S.J. Angyal and M.E. Evans, Aust. J. Chem., 25, 1495 (1972).

133. R.E. Arrick, D.C. Baker and D. Horton, Carbohydr. Res., 26, 441 (1973).

134. Z. Cecovik and Z. Tokic, J. Serb. Chem. Soc., 59, 345 (1994).

135. K.K.S. Gupta and S.N. Basu, Top. Chem. Ser. 1 (Chemical Kinetics and Reaction Mechanism), 165 (1992).

136. L.F. Sala, S. Signorella, M. Rizzotto, M.I. Franscaroli and F. Gandolfo, Can. J. Chem., 70, 2046 (1992).

137. V. Daier, S. Signorella, M. Rizzotto, M.I. Franscaroli, C. Palopoli, C. Brondino, J.M. Salas-Peregrin and L.F. Sala, Can. J. Chem., 77, 57 (1999).

138. S. Signorella, V. Daier, S. Garcia, R. Cargnello, J.C. Gonzalez, M. Rizzotto and L.F. Sala, Carbohydr. Res., 316, 14 (1999).

139. M. Rizzotto, S. Signorella, M.I. Franscaroli, V. Daier and L.F. Sala, J. Carbohydr. Chem., 14, 45 (1995).

140. S. Signorella, M. Rizzotto, V. Daier, M.I. Franscaroli, C. Palopoli, D. Martino, A. Boussecksou and L.F. Sala, J. Chem. Soc. Dalton Trans., 1607 (1996).

141. V. Roldan, J.C. Gonzalez, M. Santoro, S. Garcia, N. Casado, S. Olivera, J.C. Boggio, J.M. Salas-Peregrin, S. Signorella and L.F. Sala, Can. J. Chem., 80, 1676 (2002).

142. S. Signorella, S. Gracia and L.F. Sala, Polyhedron, 16, 701 (1997).

143. S. Signorella, M. Santoro, C. Palopoli, C. Brondino, J.M. Salas-Pelegrin, M. Quiroz and L.F. Sala, Polyhedron, 17, 2739 (1998).

144. L.F. Sala, C. Palopoli and S. Signorella, Polyhedron, 14, 1725 (1995).

145. M. Rizzotto, M.I. Frascaroli, S. Signorella and L.F. Sala, Polyhedron, 15, 1517 (1996).

146. S. Signorella, R. Lafarga, V. Daier and L.F. Sala, Carbohydr. Res., 324, 127 (2000)

147. J.F. Perez-Benito, C. Arias, R.M. Rodriguez and M. Ros, New J. Chem., 22, 1445 (1998).

148. Z. Khan and Kabir-ud-Din, Indian J. Chem., 39A, 522 (2000).

149. S. Signorella, M.I. Frascaroli, S. Garcia, M. Santoro, J.C. Gonzalez, C. Palopoli, V.N. Casado and L.F. Sala, J. Chem. Soc. Dalton Trans, 1617 (2000).

150. V. Roldan, M. Santoro, J.C. Gonzalez, J.M. Salas-Peregrin, S. Signorella and L.F. Sala, J. Inorg. Biochem., 98, 347 (2000).

151. J.C. Gonzalez, V. Daier, S. Garcia, B.A. Goodman, A.M. Atria, L.F. Sala and S. Signorella, J. Chem. Soc. Dalton Trans., 15, 2288 (2004).

152. J.C. Gonzalez, S. Garcia, N. Mamana, L.F. Sala and S. Signorella, Inorg. Chem. Commun., 5, 437 (2006)

153. S. Garcia, L. Cilluo, M.S. Olivera, J.C. Gonzalez, S. Bellu, A. Rockembauer, L. Korecz and L.F. Sala, Polyhedron, 25, 1483 (2006).

154. M.I. Frascaroli, J.M. Salas-Peregrin, L.F. Sala and S. Signorella, Polyhedron, 28, 1049 (2009).

155. M.I. Frascaroli, S. Signorella, J.C. Gonzalez, M.F. Mangiameli, S. Garcia, E.R. de Celis, L. Piehl, L.F. Sala and A.M. Atria, Polyhedron, 30, 1914 (2011).

156. V.K. Sharama and R.C. Rai, J. Indian Chem. Soc., 60, 747 (1983).

157. M. Singh, Manhas, P. Kumar, A.A. Hashmi and Z. Khan, Russian in Kinetika i Kataliz, 50, 90 (2009).

158. R. Varadarajan and R.K. Dhar, Indian J. Chem., 25A, 474 (1986).

159. R.K. Dhar, Indian J. Chem., 31A, 97 (1992).

160. G.L. Agrawal and S. Tiwari, Oxid. Commun., 15, 85 (1992).

161. G.L. Agrawal and S. Tiwari, React. Kinet. Catal. Lett., 49, 361 (1993).

162. S. Tiwari, Ph.D. Thesis, Dr. H.S. Gour University, Sagar, India (1989).

163. J.V. Singh, K. Mishra, A. Pandey and G.L. Agrawal, Oxid. Commun., 26, 72 (2003)

164. J.V. Singh, K. Mishra and A. Pandey, Oxid. Commun., 26, 80 (2003). 165. J.V. Singh, K. Mishra and A. Pandey, Bull. Pol. Acad. Sci., 51, 35 (2003).

166. J.V. Singh, K. Mishra and A. Pandey, Oxid. Commun., 26, 235 (2003).

167. J.V. Singh, A. Awasthi, K. Mishra, G.L. Agrawal and A. Pandey, (Unpublished Work).

168. R. Jain, Ph.D. Thesis, Dr. H.S. Gour University, Sagar, India (1996).

169. S.D. Dhage, S.G. Shirodkar, D.R. Munde and S.P. Pachling, Int. J. Chem. Sci., 7, 423 (2009).

170. A. Tomar and A. Kumar, Asian J. Chem., 18, 3053 (2006).

171. A. Tomar and A. Kumar, Asian J. Chem., 18, 3073 (2006).

172. A. Tomar and A. Kumar, J. Indian Chem. Soc., 83, 1153 (2006).

173. A. Tomar and A. Kumar, J. Indian Chem. Soc., 84, 1162 (2007).

174. A. Tomar and A. Kumar, Oxid. Commun., 30, 88 (2007). 